\title{
LOCKING UP THOSE DANGEROUS INDIANS FOR GOOD: AN EXAMINATION OF CANADIAN DANGEROUS OFFENDER Legislation as Applied to Aboriginal Persons
}

\author{
DAVID MILWARD*
}

This article examines the systemic reasons behind Aboriginal over-representation as Dangerous Offenders (DO) subject to indefinite detention. Colonialism has left behind various social traumas that continue to devastate Aboriginal communities. It is not surprising that significant numbers of Aboriginal persons accumulate lengthy violent criminal histories such that they come under the radar of the DO regime. One approach this article will stress is a call for greater emphasis on preventative social programming, and less emphasis on incarceration after the fact. This may lead to less Aboriginal over-incarceration generally, but also less Aboriginal over-representation as DOs, and less demand on resources over the long run. Secondly, the article also includes a review of case law where Aboriginal accused have been subjected to DO determinations. The conclusion is that courts are placing greater priority on the avoidance of harm to the public, to the point of marginalizing meaningful consideration of the background circumstances of Aboriginal accused, and of different approaches to long-term supervision that are grounded in Aboriginal cultures and may be more cost-effective. The article calls for greater judicial awareness and sensitivity towards the alternatives, as well as the development of an Aboriginal-specific risk assessment instrument that stresses dynamic instead of static factors.
Cet article examine les raisons systémiques de la surreprésentation autochtone chez les délinquants dangereux passibles de détention à durée indéterminée. Le colonialisme a causé plusieurs traumatismes sociaux qui continuent de dévaster les communautés autochtones. Il n'est pas surprenant qu'un nombre important d'Autochtones cumulent de longs antécédents de violence criminelle de sorte à devenir des délinquants dangereux. Cet article souligne l'importance d'une plus grande emphase sur les programmes sociaux préventifs et moins d'emphase sur l'incarcération après le délit. Cette approche pourrait mener à une moins grande surreprésentation autochtone en général, mais aussi à une moins grande surreprésentation autochtone chez les délinquants dangereux, et une moins grande demande de ressources à long terme. Puis, l'article comprend aussi une étude de la jurisprudence où des accusés autochtones étaient passibles de déclaration de délinquant dangereux. En conclusion, les tribunaux accordent plus de poids à éviter un préjudice au public, au point de marginaliser la considération importante du contexte des circonstances des accusés autochtones, ainsi que de différentes approches de supervision à long terme entérinées dans la culture autochtone pouvant s'avérer plus efficace. L'article fait appel à une plus grande sensibilisation et sensibilité judiciaire à l'égard de solutions de rechange et au développement d'un instrument d'évaluation de risque spécifique aux Autochtones qui souligne les facteurs dynamiques au lieu des facteurs statiques.

\section{TABLE OF CONTENTS}

I. INTRODUCTION . . . . . . . . . . . . . . . . . . . . . . . . . . . . . . . . . . . . 620

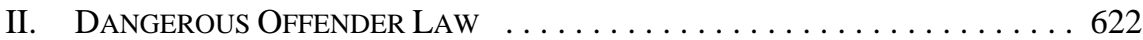

III. INTERGENERATIONAL TRAUMA AND ABORIGINAL CRIME . . . . . . . . . 625

IV. JUSTICE REINVESTMENT . . . . . . . . . . . . . . . . . . . 630

V. Risk ASSESSMENT IN DANGEROUS OFFENDER HEARINGS . . . . . . . . 636

A. Reasonable Doubt in Favour of A LONG TERM OfFEndER . . . 639

B. Factors in FAVOUR of A DANGEROUS OFFENDER ORdER . . . . . . 642

Assistant Professor, Faculty of Law, University of Manitoba. The author would like to thank the Department of Sociology at the University of Manitoba for their generous financial support, as well as Debra Parkes for her insightful feedback on an earlier draft, the peer reviewers for their helpful feedback, as well as Konstantin Pethoukov and Julia Peristerakis for their research assistance. 
C. Avoidance of Risk to the Public . . . . . . . . . . . . . . . . 644

D. Aboriginal Alternatives AcCePted . . . . . . . . . . . . . 645

E. Aboriginal Alternatives Marginalized . . . . . . . . . . . . 647

F. STANDARD Risk ASSESSEMENT CONTESTED . . . . . . . . . . . . 650

VI. RISK ASSESSMENT FOR ABORIGINAL ACCUSED RECONSIDERED . . . . . . . 651

VII. CONCLUSION . . . . . . . . . . . . . . . . . . . . . . . . . 657

\section{INTRODUCTION}

There has been much focus on Aboriginal justice initiatives resembling restorative justice as responses to the well-known problem of Aboriginal over-incarceration. ${ }^{1} \mathrm{~A}$ relatively unexplored topic is Aboriginal persons who are designated as Dangerous Offenders (DOs) subject to indeterminate and preventative detention upon successful application by the Crown. Aboriginals are over-represented as DOs as of 2011, at 26.4 percent of 458 DOs $^{2}$ despite amounting to 4.3 percent of the Canadian population as of $2011 .^{3}$

The article explores the extent to which Aboriginal accused can be safely managed under a Long Term Offender (LTO) order instead of being detained indefinitely as DOs, but it also explores preventative solutions that can minimize the need for future DO applications. Social conditions left behind by colonialism inflict multiple and severe traumas on many Aboriginal peoples over the course of their lives. Significant numbers of Aboriginals are so deeply damaged, and thus may have developed dangerous habits and behaviours that are so deeply ingrained, that they will bring themselves within the radar of the Canadian DO regime. Tweaking sentencing rules, or DO hearing practices, or relying on incarceration will do little to change this on any fundamental level. If Canada continues to prioritize incarceration "after the fact," the social conditions behind much of Aboriginal crime will continue unabated. This policy will not only continue Aboriginal over-incarceration generally, but will also ensure a steady stream of Aboriginal DOs for years to come. Canada must instead consider an overhaul of criminal justice policy in favour of justice reinvestment. Canada must work in genuine partnership with Aboriginal communities to develop social programs that include the healing resources from Aboriginal cultures that can repair the social damage left behind by colonialism. Such an approach may prove not just more effective, but also more costeffective in the long run. There is increasing empirical evidence that supports this call for a change in policy.

Justice reinvestment in preventative programming for Aboriginal peoples should not be the only emphasis though. More constructive approaches must also be pursued for the significant number of Aboriginal persons who currently are, or will soon be, serving indeterminate detention for the rest of their lives. A comprehensive overview of case law

For recent examples, see Hadley Friedland, "Different Stories: Aboriginal People, Order, and the Failure of the Criminal Justice System” (2009) 72:1 Sask L Rev 105; David Milward \& Debra Parkes, “Gladue: Beyond Myth and Towards Implementation in Manitoba” (2011) 35:1 Man LJ 84.

$2 \quad$ Public Safety Canada, Corrections and Conditional Release Statistical Overview: Annual Report 2011 (Ottawa: Public Safety Canada, 2011), online: Government of Canada: Public Safety Canada $<$ http://www.publicsaftey.gc.ca/cnt/rsrcs/pblctns/2011-ccrs/Index-eng.aspx> at 103 [Annual Report 2011].

3 Statistics Canada, Aboriginal Peoples in Canada: First Nations People, Metis and Inuit: National Household Survey, 2011 (Ottawa: Minister of Industry, 2013) at 6. 
where Aboriginal accused were subjected to DO hearings reveals a number of themes. Canadian courts, and the disciplines from which they draw expert witnesses for DO determinations, rely heavily on risk assessment instruments like Static-99 and the Hare Psychopathy Checklist (PCL-R) that stress static factors in the form of past criminal misconduct. There can also be subjectivity in the application of these instruments, PCL-R in particular. Indeed, experts in DO hearings have often come up with different results in their application of PCL-R. More fundamentally, in those cases where the accused is a prima facie public danger for purposes of the DO provisions, the experts often divide sharply over whether the risk can be managed safely under an LTO order instead of a DO order. There are times when judges hold the prosecution strictly to proving the grounds needed for a DO designation beyond a reasonable doubt, with the result of making an LTO order. These are in the distinct minority, however. Some cases see an apparent deadlock between the opinions of the expert witnesses on whether the accused's risk can be safely managed through an LTO instead of a DO. Such cases are often resolved through certain factors that tip the analysis in favour in granting a DO order. These factors include the accused's history of not complying with prior court orders or supervisory programs, the accused's lack of demonstrable remorse or acceptance of responsibility, and credibility problems with the expert witness who favours an LTO for the accused. Other cases, however, do not appear to have any such factors to break the dead lock between the expert witnesses and to tip the judges towards the DO order. In other words, there may not be a clear basis on which to prefer the evidence of the expert calling for a DO over the evidence of the expert calling for an LTO. Such cases have frequently seen judges exercise caution with a preference for assuring public safety, perhaps to the point of raising questions about whether the burden of proof is practically on the defence instead of the Crown.

This dynamic can extend to when LTO supervisory plans grounded in Aboriginal cultures, where the accused may not have had previous access to culturally appropriate programming, are presented as alternatives to the courts. Some decisions have seen an acceptance of these arguments in favour of an LTO order, but they remain in the clear minority. Many other judges again continue to err on the side of caution and demonstrate a preference for assuring public safety through a DO order. This is a concerning trend as courts are required to consider the background circumstances of Aboriginal offenders in deciding whether to grant an LTO or go with a DO, and one must wonder whether this requirement is being routinely marginalized.

This article will argue that addressing this trend may require a different methodology for assessing risk, at least for Aboriginal accused. The standard risk assesments like Static-99 and PCL-R are grounded squarely in past convictions and instances of misbehaviour. This methodology for risk assessment gives insufficient consideration to dynamic factors (that is, factors describing present progress with behaviour) that may be more accurately predictive of Aboriginal risk and more relevant to the criminogenic needs of Aboriginal accused. This perhaps mandates the development of an Aboriginal-specific risk instrument that emphasizes dynamic factors such as current progress with behaviour and participation in culturallyappropriate programming. The article begins with an overview of Canadian law on the DO and LTO designations. 


\section{DANGEROUS OFFENDER LAW}

The first prerequisite for a DO finding under section 752 of the Criminal Code is that the accused committed a "serious personal injury" offence other than murder or treason that involves violence against another person, and endangers either the life or safety or psychological well-being of the victim. ${ }^{4}$ The "serious personal injury" offence may either be an offence subject to ten years imprisonment or more, or a sexual offence. ${ }^{5}$

Section 753(1) sets out a second prerequisite of danger to the public on the part of the accused. The section provides alternate bases on which an accused can be found to be dangerous to the public, either a pattern of repetitive behaviour likely to cause death or injury and showing a lack of self-restraint, a pattern of persistent aggressive behaviour that shows indifference towards reasonably foreseeable consequences to other people, if the "serious personal injury" offence under section 752 is of such a singularly brutal nature as to show an unlikelihood of self-restraint, or an inability to control sexual impulses with a concurrent likelihood of harming someone else. ${ }^{6}$ Only one of these alternate bases needs to be demonstrated in order to satisfy the dangerousness prerequisite.

Under section 753(4.1), the accused may be subject to indeterminate detention if the prerequisites for a DO designation are satisfied, and is not to be released until "there is a reasonable expectation that a lesser measure ... will adequately protect the public against the commission by the offender of murder or a serious personal injury offence."7

Under section 753(5), if the court does not find the accused to be a DO, the accused can be sentenced as an LTO, or simply sentenced for the offence for which the accused has been convicted. ${ }^{8}$ An LTO order requires an offence for which the accused could be sentenced to two years or more, a substantial risk of re-offending, and a reasonable possibility of eventual control of the risk in the community. ${ }^{9}$ Section $753.1(3)$ mandates that once an LTO designation is made, the accused must receive a sentence for the offence on which he or she is convicted, with a minimum of two years, and must be subject to a long-term supervision order that does not exceed ten years. ${ }^{10}$

The relationship between the DO and LTO provisions was explained by the Supreme Court of Canada in R. v. Johnson. ${ }^{11}$ Whenever the Crown brings forward a DO application, the presiding judge must simultaneously give consideration to whether an LTO order is sufficient to protect the public in place of a DO order. ${ }^{12}$ Even if all the statutory requirements for a DO designation are met, it does not necessarily follow that a DO order will be made. ${ }^{13}$

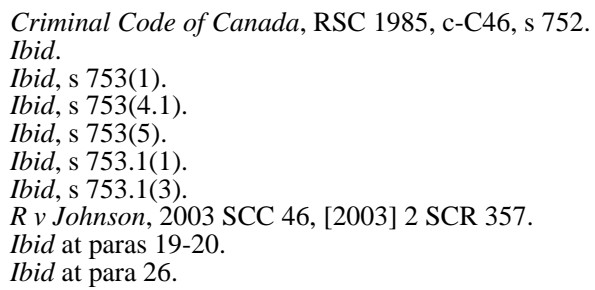


The judge must consider whether an LTO order can reasonably manage the risk presented by the accused. ${ }^{14}$

There are additional principles to be considered where Aboriginal accused are concerned. Section 718.2(e) of the Criminal Code reads in part:

A court that imposes a sentence shall also take into consideration the following principles:

all available sanctions other than imprisonment that are reasonable in the circumstances should be considered for all offenders, with particular attention to the circumstances of aboriginal offenders. ${ }^{15}$

The first Supreme Court of Canada case to consider this provision was $R$. v. Gladue ${ }^{16}$ where the Court noted that this provision was enacted in response to alarming evidence that Aboriginal peoples were incarcerated disproportionately to non-Aboriginal people in Canada. ${ }^{17}$ Section 718.2(e) is thus a remedial provision, enacted specifically to oblige the judiciary to do what is within their power to reduce the over-incarceration of Aboriginal people and to seek reasonable alternatives for Aboriginal people who come before them. ${ }^{18}$ Justice Cory adds:

It is often the case that neither aboriginal offenders nor their communities are well served by incarcerating offenders, particularly for less serious or non-violent offences. Where these sanctions are reasonable in the circumstances, they should be implemented. In all instances, it is appropriate to attempt to craft the sentencing process and the sanctions imposed in accordance with the aboriginal perspective. ${ }^{19}$

A judge must take into account the background and systemic factors that bring Aboriginal people into contact with the justice system when determining sentence. Justice Cory describes these factors as follows:

The background factors which figure prominently in the causation of crime by aboriginal offenders are by now well known. Years of dislocation and economic development have translated, for many aboriginal peoples, into low incomes, high unemployment, lack of opportunities and options, lack or irrelevance of education, substance abuse, loneliness, and community fragmentation. ${ }^{20}$

Ibid at paras 30-31, 36.

Criminal Code, supra note 4, s 718.2(e).

$R v$ Gladue, [1999] 1 SCR 688 [Gladue].

Ibid at para 50. At para 58, Justice Cory cited some statistics on over-representation:

By 1997, aboriginal peoples constituted closer to 3 percent of the population of Canada and amounted to 12 percent of all federal inmates.... The situation continues to be particularly worrisome in Manitoba, where in 1995-96 they made up 55 percent of admissions to provincial correctional facilities, and in Saskatchewan, where they made up 72 percent of admissions. A similar, albeit less drastic situation prevails in Alberta and British Columbia.

As noted earlier in this article, the rate of over-representation has increased in the years since Gladue was decided.

Ibid at paras 64-65.

Ibid at para 74.

Ibid at para 67. 
Section 718.2(e) requires a "different methodology" for assessing a fit sentence for an Aboriginal person. ${ }^{21}$ A judge must consider the role of systemic factors in bringing a particular Aboriginal accused before the court, ${ }^{22}$ and is obligated to obtain that information with the assistance of counsel, or through pre-sentence reports. A judge must also obtain information on community resources and treatment options that may provide alternatives to incarceration. ${ }^{23}$ In R. v. Kakekagamick, the Ontario Court of Appeal stated that Crown prosecutors and defence counsel alike are under a positive duty to provide information and submissions on Gladue factors where appropriate. ${ }^{24}$ The judge, even when faced with an inadequate report or inadequate assistance from counsel, is still obliged to try and obtain the information necessary for a meaningful consideration of Gladue. ${ }^{25}$

The Supreme Court has added further commentary in a recent decision, $R$. v. Ipeelee. Justice LeBel expressed concern about lower courts limiting the use of non-custodial sentences under Gladue to less serious offences for which an accused, Aboriginal or nonAboriginal, would get probation or a conditional sentence anyway. Justice LeBel condemned the practice as betraying: "a fundamental misunderstanding and misapplication of both s. 718.2(e) and this Court's decision in Gladue."26 Ipeelee reinforces that there is often justification for sentencing Aboriginal offenders differently under section 718.2(e), and that justification is tied to colonialism itself. Justice LeBel states: "The overwhelming message emanating from the various reports and commissions on Aboriginal peoples' involvement in the criminal justice system is that current levels of criminality are intimately tied to the legacy of colonialism”27 Justice LeBel continues:

To the extent that Gladue will lead to different sanctions for Aboriginal offenders, those sanctions will be justified based on their unique circumstances — circumstances which are rationally related to the sentencing process. Courts must ensure that a formalistic approach to parity in sentencing does not undermine the remedial purpose of s. $718.2(e) .^{28}$

The British Columbia Court of Appeal states that the Gladue principles must also be taken into consideration when adjudicating whether an Aboriginal accused should be designated as a DO or as an LTO. ${ }^{29} \mathrm{~A}$ judge must consider the role that the Gladue factors have had in shaping the accused's criminal history, and whether culturally sensitive programs can reasonably manage the risk involved with an Aboriginal accused. We will see that there are real questions surrounding the extent to which this principle is being realized. But first, this article will examine the question of what can be done to minimize as early as possible the necessity of subjecting Aboriginal persons to DO hearings.

$R v$ Wells, 2000 SCC 10, [2000] 1 SCR 207 at para 44.

Gladue, supra note 16 at paras 66, 69.

Ibid at paras 83-84; see also $R v$ Bodaly, 2010 BCCA 9, [2010] BCJ 172.

$R v$ Kakekagamick, (2006) 81 OR (3d) 644, 214 OAC 127 at para 44. With respect to defence counsel's obligations, Legal Aid Ontario has taken steps to develop competence among defence lawyers to represent Aboriginal clients in criminal matters, including through the implementation of "Gladue Panel Standards" (see Legal Aid Ontario, "Gladue Panel Standards,” online: Legal Aid Ontario <http://www. legalaid.on.ca/en/info/panel_standards_gladue.asp>).

Ibid at para 45.

$R$ v Ipeelee, 2012 SCC 13, [2012] 1 SCR 433 at para 63 [Ipeelee].

Ibid at para 77 .

Ibid at para 79.

$R v$ Ladue, 2011 BCCA 101, [2011] BCJ no 366 (QL) at paras 63, 82 [Ladue]. Appeal denied in Ipeelee, supra note 26 at para 98 . 


\section{INTERgENERATIONAL TRAUMA AND AboriginAl CRIME}

Empirical studies verify that social conditions have a strong role in crime rates, which also explains Aboriginal over-representation as DOs. Growing up in an abusive home environment increases the chances of children, and adolescents, later becoming involved with lives of crime, including violent offences and drug related offences. ${ }^{30}$ When male children witness the abuse of their mothers in the home, it significantly increases their chances of becoming intimate abusers later in life, both of their partners ${ }^{31}$ as well as their children. ${ }^{32}$ Being at risk for mental health problems stemming from abuse while young also increases the risk for involvement with the criminal justice system. ${ }^{33}$ The more sexual abuse that one experiences as a child, the more it increases the chances of engaging in substance abuse and self-injurious behaviour. ${ }^{34}$

Many studies have found a correlation between poverty and higher crime rates. ${ }^{35}$ This is apparently true even for the most serious of offences, including homicide offences. ${ }^{36}$ Poverty and lack of employment opportunities have also been found to have a positive correlative relationship with gang membership. ${ }^{37}$ Lack of education also increases the chances of falling into a life of crime. ${ }^{38}$ Conversely, greater education and literacy decreases the chances of young persons getting caught up in criminal lifestyles. ${ }^{39}$ Poverty also increases the

30 Cindy Sousa et al, "Longitudinal Study on the Effects of Child Abuse and Children's Exposure to Domestic Violence, Parent-Child Attachments, and Antisocial Behavior in Adolescence” (2011) 26:1 Journal of Interpersonal Violence 111; Emily Salisbury, Kris Henning \& Robert Holdford, "Fathering by Partner-Abusive Men: Attitudes on Children's Exposure to Interparental Conflict and Risk Factors for Child Abuse” (2009) 14:3 Child Maltreatment 232.

31 Jennifer Wareham, Denise Paquette Boots \& Jorge M Chavez, “A Test of Social Learning and Intergenerational Transmission Among Batterers” (2009) 37:2 J Crim J 163 at 163; Patrick Lussier, David P Farrington \& Terrie E Moffitt, "Is the Antisocoal Child Father of the Abusive Man? A 40-year Propsective Longtitudinal Study on the Development Antecedents of Intimate Partner Violence” (2009) 47:3 Criminol 741 at 741-42.

32 Amy R Murrell, Karen A Christoff \& Kris R Henning, "Characteristics of Domestic Violence Offenders: Associations with Childhood Exposure to Violence” (2007) 22 J Fam Viol 523 at 523.

33 Carol A Schubert, Edward P Mulvey \& Cristie Glasheen, "Influence of Mental Health and Substance Use Problems and Criminogenic Risk on Outcomes in Serious Juvenile Offenders” (2011) 50:9 Journal of the American Academy of Child and Adolescent Psychiatry 925 at 925; Dannia Southerland, Cecilia E Casanueva \& Heather Ringeisen, "Young Adult Outcomes and Mental Health Problems Among Transition Age Youth Investigated for Maltreatment During Adolescence” (2009) 31:9 Child and Youth Services Review 947 at 947. Juliet Robboy \& Kristen G Anderson, “Intergenerational Child Abuse and Coping”(2011) 26:17 Journal of Interpersonal Violence 3526 at 3528.

35 Some of the most recent ones include Marc Hooghe et al, "Unemployment, Inequality, Poverty \& Crime: Spatial Distribution Patterns of Criminal Acts in Belgium, 2001-06” (2011) 51:1 Brit J Crim 1 at 1; Kaaryn Gustafson, "Criminal Law: The Criminalization of Poverty" (2009) 99:3 J Crim L \& Criminology 643; Scott Atkins, "Racial Segregation, Concentrated Disadvantage, and Violent Crime” (2009) 7:1 Journal of Ethnicity in Criminal Justice 30 at 30.

36 Some of the most recent studies on this include David Eitle, Stewart J D'Alessio \& Lisa Stolzenberg, “Economic Segregation, Race, and Homicide” (2006) 87:3 Social Science Quarterly 638 at 638; Jesenia M Pizarro \& Jean Marie McGloin, "Explaining Gang Homicides in Newark, New Jersey: Collective Behavior or Social Disorganization?” (2006) 34:2 J Crim J 195; William Alex Pridemore, “A Methodological Addition to the Cross-National Empirical Literature on Social Structure and Homicide: A First Test of the Poverty-Homicide Thesis” (2008) 46:1 Criminol 133 at 133.

37 Richard Spano, Joshua D Freilich \& John Bolland, “Gang Membership, Gun Carrying, and Employment: Applying Routine Activities Theory to Explain Violent Victimization Among Inner City, Minority Youth Living in Extreme Poverty” (2008) 25:2 Just Q 381 at 382, 395-97, 401, 403.

38 Ricardo Sabates, "Educational Attainment and Juvenile Crime: Area-Level Evidence Using Three Cohorts of Young People” (2008) 48:3 Brit J of Crim 395 at 395.

39 James S Vacca, "Crime can be prevented if schools teach juvenile offenders to read" (2008) 30:9 Children and Youth Services Review 1055 at 1055-57. 
occurrence of domestic violence because it leaves battered women with fewer resources to obtain independence from abusive partners. ${ }^{40}$

Hard drug use has also been found to increase the chances of involvement with the justice system, ${ }^{41}$ as well as propensities towards violent crime. ${ }^{42}$ Having experienced racial discrimination has also been found to increase involvement with crimes of violence. ${ }^{43}$ These problems can be multi-layered. A study by Carter Hay and others argues that community poverty exacerbates the effects that unstable family environments has on levels of crime. ${ }^{44}$ Preeti Chauhan and N. Dickon Reppuci's study asserts that poverty, coupled with exposure to violence while young, whether growing up in an abusive environment or witnessing it first-hand, can increase propensity towards juvenile violence. ${ }^{45}$ Poverty has been found to increase the probabilities of substance abuse, and both in turn increase the probabilities of criminal behavior. ${ }^{46}$ An American study has also found that childhood neglect and childhood poverty together are predictive of both mental health problems, including post-traumatic stress disorder and major depressive disorder, as well as adult arrest. ${ }^{47}$ A New Zealand study found a correlation between poverty and self-reported crimes or official convictions of youth. ${ }^{48}$ This relationship was however modified when measured against intervening factors. Positive familial relationships, positive peer relationships, and improved scholastic performance mitigated the tie between poverty and crime. The lack of positive familial or peer relationships, and poorer school performance, reinforced the correlation between poverty and crime.

Shelby AD Moore, "Understanding the Connection between Domestic Violence, Crime, and Poverty: How Welfare Reform May Keep Battered Women From Leaving Abusive Relationships” (2003) 12 Tex J Women \& L 451 at 454-56; Diane M Purvin, "Weaving a Tangled Safety Net: The Intergenerational Legacy of Domestic Violence and Poverty” (2003) 9 Violence against Women 1263 at 1263-64, 127576.

41 Steve Sussman et al, "Prediction of Violence Perpetration Among High-risk Youth” (2004) 28:2 American Journal of Health Behavior 134.

42 Emma L Barrett, Katherine A Mills \& Maree Teesson, "Hurt People Who Hurt People: Violence Amongst Individuals with Comorbid Substance Abuse Disorder and Posttraumatic Stress Disorder" (2011) 36:7 Addictive Behaviors 721.

$43 \quad$ Elizabeth Reed et al, "Experiences of Racial Discrimination \& Relation to Violence Perpetration and Gang Involvement among a sample of Urban African American Men” (2010) 12:3 Journal of Immigrant \& Minority Health 319; Preeti Chauhan, N Dickon Reppucci \& Eric N Turkheimer, "Racial Differences in the Associations of Neighbourhood Disadvantage, Exposure to Violence, and Criminal Recidivism among Female Juvenile Offenders” (2009) 27:4 Behav Sci \& L 351.

44 Carter Hay et al, "The Impact of Community Disadvantage on the Relationship between the Family and Juvenile Crime” (2006) 43:4 Journal of Research in Crime \& Delinquency 326 at 343-46.

$45 \quad$ Preeti Chauhan \& N Dickon Reppucci, “The Impact of Neighbourhood Disadvantage and Exposure to Violence on Self-Report of Antisocial Behavior Among Girls in the Juvenile Justice System” (2009) 38:3 Journal of Youth \& Adolescence 401.

46 Alison Ritter \& Jennifer Chalmers, “The Relationship between Economic Conditions and Substance Use and Harms” (2011) 30:1 Drug \& Alcohol Review 1 at 1-2.

$47 \quad$ Valentina Nikulina, Cathy SpatzWidom \& Sally Czaja, “The Role of Childhood Neglect and Childhood Poverty in Predicting Mental Health, Academic Achievement and Crime in Adulthood” (2011) 48:3/4 American Journal of Community Psychology 309.

48 David Fergusson, Nicola Swain-Campbell \& John Horwood, "How does Childhood Economic Disadvantage Lead to Crime?” (2004) 45:5 Journal of Child Psychology \&Psychiatry 956 at 956, 96364. 
Instability of home placement due to being in a child welfare system has been found to increase juvenile delinquency for children, male children in particular, ${ }^{49}$ as well as adult criminality. ${ }^{50}$

A fact of Canadian history is that its Aboriginal peoples were subjected to the harmful processes of colonization, which included military conquest, ${ }^{51}$ the acquisition of Aboriginal land bases through treaties, ${ }^{52}$ and policies of assimilation that attempted to force Aboriginal peoples to abandon their own cultures in favour of Euro-Canadian lifestyles by criminalizing cultural activities like the potlatch. ${ }^{53}$ An especially harmful part of the history of colonization was forcing Aboriginal children to attend residential schools. ${ }^{54}$ Many were physically and sexually abused, and thus would pass intergenerational trauma on to their descendants. ${ }^{55}$ Many were forced to abandon their languages and culture. Many left not having acquired the skills or education to gain meaningful employment, thus contributing, along with economic colonialism and ongoing workplace discrimination, to the impoverishment of Aboriginal communities. $^{56}$

The colonization of Aboriginal peoples has introduced all of the previously mentioned social contributors to crime into Aboriginal communities, and ensured that they have persisted as an enduring legacy generation after generation. Residential schools, in particular, have had a very strong role in both severely damaging its students, but also in introducing massive trauma into Aboriginal communities that gets passed on from generation to generation. ${ }^{57}$ This point has been substantiated in several studies.

The Assembly of First Nations also did a study based on interviews with 30 Aboriginal and 30 non-Aboriginal federal inmates. About one half of Aboriginal inmates had a history

Joseph P Ryan \& Mark F Testa, “Child Maltreatment and Juvenile Delinquency: Investigating the Role of Placement and Placement Instability” (2005) 27:3 Children \& Youth Services Review 227 at 227, 244-46; see also Joseph P Ryan et al, "Juvenile Delinquency in Child Welfare: Investigating Group Home Effects” (2008) 30:9 Children \& Youth Services Review 1088.

50 Sarah DeGue \& Cathy Spatz Widom, "Does Out-of-Home Placement Mediate the Relationship Between Child Maltreatment and Adult Criminality” (2009) 14:4 Child Maltreatment 344 at 344-47, 351-52.

Although Canada did not fight wars against its Indigenous peoples as often as the United States, they did use military subjugation on occasion. A particularly notorious example was the defeat of the Rebellion of 1885 involving Métis and Cree groups. See Olive Patricia Dickason with William Newbigging, A Concise History of Canada's First Nations, 2d ed (Don Mills, Ontario: Oxford University Press, 2006) at 234-44; see also JR Miller, Skyscrapers Hide the Heavens: A History of Indian-White Relations in Canada (Toronto: University of Toronto Press, 2000) at 202-11.

52 For a historical overview of the numbered treaties in the western provinces, see JR Miller, ibid at 21624; Dickason, ibid at 186-93.

Miller, ibid at 260-63; Dickason, ibid at 199, 241.

Miller, ibid at 135-36, 340-41; Dickason, ibid at 227-29.

Dawn Smith, Colleen Varcoe \& Nancy Edwards, “Turning Around the Intergenerational Impact of Residential Schools on Aboriginal People: Implications for Health Policy and Practice” (2005) 37:4 Canadian Journal of Nursing Research 38 at 40, 52-53; Lori Haskell \& Melanie Randall, "Disrupted Attachments: A Social Context Complex Trauma Framework and the Lives of Aboriginal Peoples in Canada” (2009) 5:3 Journal of Aboriginal Health 48 at 50-51, 53, 82-83.

56 Joan Kendall, “Circles of Disadvantage: Aboriginal Poverty and Underdevelopment in Canada” (2001) 31:1/2 American Review of Canadian Studies 43 at 44-49.

Cheryle Partridge, "Residential Schools: The Intergenerational Impacts on Aboriginal Peoples” (2010) 7 Native Social Work Journal 33 at 50-58; John Lederman, "Trauma and Healing in Aboriginal Families and Communities” (1999) 2:1 Native Social Work Journal 59 at 62-63; Amy Bombay, Kim Matheson \& Hymie Anisman "Intergenerational Trauma: Convergence of Multiple Processes among First Nations peoples in Canada” (2009) 5:3 Journal of Aboriginal Health 6 at 14-16, 22-24; Laurence Kirmayer, Cori Simpson \& Margaret Cargo, "Healing Traditions: Culture, Community and Mental Health Promotion with Canadian Aboriginal Peoples” (2003) 11 supp Australasian Psychiatry S15 at S18. 
of child welfare placement in comparison to one quarter of non-Aboriginal inmates. Aboriginal inmates had more unstable home environments than non-Aboriginal inmates. This conclusion was based on Aboriginal inmates' own perception of their home environments, as well as identified markers such as family violence, substance abuse in the home, and parental neglect. Aboriginal inmates more often developed an attachment to culture (76 percent) after coming into prison in comparison to before coming to prison (50 percent). ${ }^{58}$ In addition, 35 of 172 Aboriginal inmates indicated that they had attended a residential school. These inmates, on a scale of one (very negative) to five (very positive), gave their residential school experience an average of 1.78. Eighty-three percent of these inmates indicated having no access to cultural or spiritual activities while in residential school. Seventy-seven percent of these inmates indicated having been sexually or physically abused while in residential school, mostly by school staff. ${ }^{59}$

Jessica Ball explains with reference to a qualitative study involving interviews with 80 Aboriginal fathers in British Columbia:

Eighty-two percent of fathers referred in some way to the disruption of intergenerational bonds and transmission of language and culture in their explanatory accounts of the harsh living conditions, psychological problems, or challenging relationships in their lives, including father-child relationships. ${ }^{60}$

A study that compared Aboriginal young sexual offenders to non-Aboriginal young sexual offenders found that the Aboriginal offenders were more likely to have a history of substance abuse (56.7 to 28.6 percent), to have a history of having themselves been sexually abused (65.5 to 47.7 percent), to have had a history of being physically abused (61.4 to 46.5 percent), and to have been neglected in the home (72.6 to 32.2 percent). ${ }^{61}$

Annie Yessine and James Bonta's study, based on comparing Aboriginal youth under probation in Manitoba compared to non-Aboriginal youth, argues that Aboriginal youth are over-represented as youth offenders because they come from disadvantaged social backgrounds that include poverty, unstable family setting, and negative peer associations (for example, youth gangs). ${ }^{62}$ James Waldram interviewed many Aboriginal federal inmates in the Regional Psychiatric Centre in Saskatoon, the Saskatchewan Penitentiary, and the Stoney Mountain Penitentiary and Rockwood Institution, both in Winnipeg, in his study. Many inmates attributed their incarceration to various contributors like poverty, racism, violent or

Shelley Trevethan, Sarah Auger \& John Patrick-Moore, The Effect of Family Disruption on Aboriginal and Non-Aboriginal Inmates (Ottawa: Assembly of First Nations, 2001), online: Government of Canada Publications <http://publications.gc.ca/site/eng/380296/publication.html>.

$59 \quad$ Ibid at 36 .

60 Jessica Ball, “Indigenous Fathers’ Involvement in Reconstituting 'Circles of Care’” (2010) 45:1-2 American Journal of Community Psychology 124 at 130.

61 Erika Y Rojas \& Heather M Gretton, "Background, Offence Characteristics, and Criminal Outcomes of Aboriginal Youth Who Sexually Offend: A Closer Look at Aboriginal Youth Intervention Needs" (2007) 19:3 Sexual Abuse 257 at 267. For another study with quite similar comparisons, see Lawrence A Ellerby \& Paula McPherson, Exploring the Profiles of Aboriginal Sexual Offenders: Contrasting Aboriginal and Non-Aboriginal Sexual Offenders to Determine Unique Client Characteristics and Potential Implications for Sex Offender Assessment and Treatment Strategies (Winnipeg: Forensic Behaviourial Management Clinic, Native Clan Organization, 2002), online: Government of Canada Publications <http://publications.gc.ca/site/eng/380341/publication.html>.

62 Annie K Yessine \& James Bonta, "The Offending Trajectories of Youthful Aboriginal Offenders" (2009) 51:4 Can J Crime 435 at 436, 439. 
sexual abuse in their home environments, loss of cultural connection, loss of positive selfesteem as Aboriginal persons, and substance abuse. ${ }^{63}$

It stands to reason that the more criminogenic factors that are present in an individual's community, the more likely that individual is to build up a criminal history, become entrenched in criminal lifestyles, and become a danger to those around him or her. It is therefore not surprising to see that the backgrounds of many Aboriginal DOs can be tied in with the damage inflicted by colonialism and intergenerational trauma. This excerpt from $R$. $v$. F.R. reveals the damage inflicted directly by a residential school on a student who went on to become a DO:

Mr. [F.R.] was placed in the Lebret Residential School when he was 8 years of age for 8 months, during which time he was subjected to physical and sexual abuse. Following the family's move to Regina, he suffered racially based bullying at school, had few friends and often was involved in fights. His school attendance was poor and ended early. He achieved his Grade 9 at the age of twenty, while he was in the penitentiary.

Mr. [F.R.] has a long-standing history of alcohol and drug abuse. He began drinking at age 12 and by age 14 he was drinking on a regular basis, as much as he could, increasing as he got older. Similarly, he began using illicit substances at the age of 12, beginning with marijuana and then Restoril, Valium and speed when it was obtainable. By the age of 20 he was using cocaine, morphine, Talwin and Ritalin intravenously. ${ }^{64}$

The background of the accused in R. v. Badger reveals the role that intergenerational trauma can have in moulding a person labelled as a DO:

Steven's earliest recollections were at approximately the age of five when he lived with his family on the reserve. He indicated that at that time, reserve life involved much violence in the community. There was also violence and abuse in his home and between his family members. As a youth, he recalls being witness to drinking, fighting and abuse, particularly between his father and older brother, both of whom drank a lot. He observed his father shooting at his brother and his brother beating his father severely. Beatings also took place between his father and other brothers as well as his father and mother. Additional incidents of the use of weapons and police involvement were involved in his experiences growing up.

Insofar as his education is concerned, he dropped out of the Cote reserve school in Grade 6 after which he returned to work on the farm. His substance abuse problems began at the early age of 10 to 12 years old. He sniffed solvent and gasoline with others, particularly an older brother. His delinquency began around the age of 12 when he committed break, enters and thefts into local homes for snacks and drinks with other youths. Because of the lack of supervision that he had on the farm, his mother reported her concerns to child protection authorities and he was apprehended and placed and lived in foster care homes in the Yorkton district when he was 13 and $14 .^{65}$ 
In a very real sense, Aboriginal DOs provide the most damning proof of what colonialism has done to Aboriginal peoples. Aboriginal DOs are shaped by a multiplicity of traumas affecting their lives, from their early formative years and for long afterwards, well before a DO application is ever made. To suffer these multiple traumas over an extended period of time primes up many Aboriginal persons as candidates for DO designations. Nothing will change that unless the deep-seated problems that have beset Aboriginal communities are somehow repaired. This begs the question of what can be done about those traumas.

\section{JUSTICE REINVESTMENT}

The next set of discussions raises fundamental questions about criminal justice policies but, as we will see, take on a special relevance when it comes to Aboriginal DOs. There is no doubt that incarceration is an immensely expensive sanction to administer. As of 2010, it costs $\$ 150,808$ to keep an inmate in a maximum security institution for one year, $\$ \mathbf{\$ 9}, 219$ for medium security, and \$95,038 for minimum security. ${ }^{66}$ Howard Sapers, the Correctional Investigator of Canada, indicated in his 2009-2010 annual report that the annual cost of keeping somebody on community supervision is one-eighth the cost to keep the same person incarcerated. ${ }^{67} \mathrm{He}$ also indicated before a Senate Standing Committee on Legal and Constitutional Affairs that the Canadian Correctional Service had an annual budget of \$1.8 billion, and yet allocated only $\$ 27$ million of that for the delivery of core program services. ${ }^{68}$

It is becoming more and more obvious that prison is far more expensive than non-custodial sentences. This reality has spurred the coining of the term "Justice Reinvestment”: the idea that it will be more cost effective in the long term to invest in social programming that steers prospective offenders away from lives of crime before they even come into contact with the justice system, and to invest in more robust correctional and supervisory services for those persons who do get charged. ${ }^{69}$ The concept has been embraced by several American states as they have faced mounting correctional budgets. ${ }^{70}$

One could certainly stress a need for more extensive social programming for Aboriginal communities. What is needed is sustained and comprehensive programming that integrates Aboriginal cultures so as to best meet the needs of both communities, and individuals who may be at risk of falling into criminal lifestyles. This argument has been strenuously made with respect to mental health services for Aboriginal peoples. The idea is that Western medicine is too narrow in its approach and focus on physical and mental symptoms.

66 Annual Report 2011, supra note 2 at 26.

Howard Sapers, Annual Report of the Office of the Correctional Investigator (Ottawa: Office of the Correctional Investigator, 2010), online: Government of Canada Publications <http://publications. gc.ca/sit/eng/376221/publication.html> at 6 .

68 Office for the Correctional Investigator, Speaking Notes for Mr Howard Sapers, Correctional Investigator, "Appearance before the Senate Standing Committee on Legal and Constitutional Affairs" (14 February 2008), online: Office of the Correctional Investigator <http://www.oci-bec.gc.ca/ cnt/comm/sp-all/sp-all20080214-eng.aspx>.

$69 \quad$ Rob Allen, "Justice Reinvestment and the Use of Imprisonment: Policy Reflections from England and Wales” (2011) 10:3 Criminology \& Public Policy 617.

70 Marshall Clement, Matthew Schwartzfeld \& Michael Thompson, The National Summit on Justice Reinvestment and Public Safety: Addressing Recidivism, Crime, and Corrections Spending (New York: Council of State Governments Justice Center, 2011), online: Bureau of Justice Assistance $<$ https://www.bja.gov/Publications.aspx>; Robert Coombs, "Justice Reinvestment Approach Increases Public Safety, Cuts Millions in Spending” (2011) 54:6 Capitol Ideas 38. 
Aboriginal medicine also addresses the crucial aspects of emotional and spiritual health. Aboriginal medicine may also be more likely to reach Aboriginal individuals on a personal level. ${ }^{71}$ Peter Menzies suggests that developing a comprehensive Aboriginal healing model that integrates traditional cultures addresses will not only address individual therapeutic needs, but also community and family structures, and is therefore what is needed to undo the harm of intergenerational trauma. ${ }^{72}$ A study of 73 Aboriginal persons, mostly women and from various communities, revealed that almost all of them believed that healthy parenting from birth and onwards was crucial in reversing the fallout of the residential schools. They also believed that the development of programs in communities, grounded in Aboriginal cultures, to assist with prenatal care and early child rearing were crucial to support this. ${ }^{73}$ Several of the fathers interviewed in Ball's study expressed the hope that greater involvement of the extended family in contemporary child raising, with parallels to past kinship networks in pre-contact societies, could go a long way towards undoing the intergenerational disruption of colonialism. ${ }^{74}$

Some commentators suggest that the concept of justice reinvestment is relatively underexplored and underdeveloped, and therefore caution is still needed. ${ }^{75}$ There is, however, cause for cautious optimism when it comes to Aboriginal-specific programming. Evidencebased studies that can verify the efficacy of this approach have been slow to come, but they have started to arrive. ${ }^{76}$ Some of the studies show at the very least a reduction of identified risk factors for crime, or also establish a direct link to reduced crime rates and recidivism rates. A study of the Knaw Chi Ge Win program in northern Ontario found that integrating Aboriginal culture with mental health services resulted in lowering acute care admissions from three to four clients a year to zero to one client a year. This reflected clients becoming healthier and no longer prone to recidivism. ${ }^{77}$ An evaluative study of the Mibbinbah project

Lewis Mehl-Madrona \& Gordon Pennycook, "Construction of an Aboriginal Theory of Mind and Mental Health” (2009) 20:2 Anthropology of Consciousness 85; Robin Jones \& Andrew Day, "Mental Health, Criminal Justice and Culture: Some Ways Forward?” (2011) 19:4 Australasian Psychiatry 325; Glen McCabe, "Mind, Body, Emotions and Spirit: Reaching to the Ancestors for Healing” (2008) 21:2 Counselling Psychology Quarterly 143; Laurence J Kirmayer, Gregory M Brass \& Caroline L Tait, “The Mental Health of Aboriginal Peoples: Transformations of Identity \& Community” (2000) 45:7 Canadian Journal of Psychiatry 607; Canadian Population Health Initiative, Mentally Healthy Communities: Aboriginal Perspectives (Ottawa: Canadian Institute for Health Information, 2009).

72 Peter Menzies, "Developing an Aboriginal healing model for intergenerational trauma" (2008) 46:2 International Journal of Health Promotion \& Education 41. See also Terry L Mitchell \& Dawn T Maracle, "Healing the Generations: Post-Traumatic Stress and the Health Status of Aboriginal Populations in Canada" (2005) 2:1 Journal of Aboriginal Health 14 at 19-21; Paul Memmott, "On Regional and Cultural Approaches to Australian Indigenous Violence” (2010) 43:2 Australian \& New Zealand Journal of Criminology 333; Phillip Lane Jr, et al, Mapping the Healing Journey: The Final Report of a First Nation Research Project on Healing in Canadian Aboriginal Communities (Ottawa: Solicitor General of Canada \& Aboriginal Healing Foundation, 2002), online: Public Safety Canada <http://www.publicsafety.gc.ca/cnt/rsrcs/mppng-hlng/index-eng.aspx>..

73 Dawn Smith, Colleen Varcoe \& Nancy Edwards, "Turning Around the Intergenerational Impact of Residential Schools: Implications for Health Policy and Practice” (2005) 37:4 Canadian Journal of Nursing Research 38 at 50-51.

$74 \quad$ Ball, supra note 60 at 133-35.

75 Chris Fox, Kevin Alberton \& Frank Wharburton, “Justice Reinvestment: Can it Deliver More for Less?” (2011) 50:2 Howard Journal of Criminal Justice 119; Shadd Maruna, “Lessons for Justice Reinvestment from Restorative Justice and the Justice Model Experience: Some Tips for an 8-year-old Prodigy” (2011) 10:3 Criminology \& Public Policy 661.

76 Andrew Day et al, "Indigenous Family Violence: An Attempt to Understand the Problems and Inform Appropriate and Effective Responses to Criminal Justice System Intervention” (2012) 19:1 Psychiatry, Psychology \& Law 104.

77 Marion A Maar et al, "Innovations on a Shoestring: A Study of a Collaborative Community-based Aboriginal Mental Health Service Model in Rural Canada” (2009) 3:1 International Journal of Mental Health Systems 27 at 34. 
in Australia, a mental health program that drew on Aboriginal spirituality, observed that Aboriginal men who regularly attended the program showed decreased domestic violence incidences, and decreased dependency on substance abuse. ${ }^{78}$

Success stories come not just from Aboriginal-oriented mental health services, but also from family services, therapeutic services for survivors of trauma, and harm reduction programs. The Nimkee NupiGawagan Healing Centre in Ontario successfully treated solvent abuse in many youth, although the evidence is anecdotal. ${ }^{79}$ As another example, a study conducted in Northern Saskatchewan showed that Cree and Dene Elders' approaches to counseling and healing were effective in both reducing beatings against domestic violence victims, and in mitigating the trauma and symptoms experienced by victims after abuse. ${ }^{80}$

A study of the Sexual Abuse Intervention Program in British Columbia, which combines therapy with Aboriginal culture and spirituality, was tentatively effective in preventing sexually abused children from developing problems later on in adult life. Program participants showed a reduction in developing mental health disorders (20 percent) in comparison to a sample group who did not go through the program (48.2 percent). Improvements were also shown when it came to becoming sexually aggressive later in life (10 to 25 percent) and developing a behavior disoder (58.9 percent). ${ }^{81}$

An evaluative study was done of the Aboriginal Community Alcohol Harm Reduction Policy Demonstration Project in Ontario. ${ }^{82}$ The program itself was premised on a community providing a space where alcohol could be used, but not anywhere else in the community. The study used a survey to solicit from key stakeholders (for example, chief or counsellor) from various Aboriginal communities in Ontario their viewpoints on whether the project had reduced social problems. Responses were rated on a scale of zero (a problem never occurs) to four (a problem often occurs). Assaults went from an average rating of almost three prior to the project to approximately one and one-quarter after the project had been in operation for two years. Vandalism went from almost three to a little under one. Sexual Assaults went from almost one to zero.

Unfortunately, the current Conservative Government has made itself clear in terms of where its priorities lie. The Government's inertia against addressing Aboriginal social problems in any meaningful way is demonstrated through their gutting of the Kelowna Accord that was negotiated for 18 months between the federal government led by former Prime Minister Paul Martin and Aboriginal leaders. It was finalized on November of 2005. It promised $\$ 5.1$ billion over ten years to address Aboriginal social problems in areas such

Jack Bulman \& Rick Hayes, "Mibbinbah and Spirit Healing: Fostering Safe, Friendly Spaces for Indigenous Males in Australia” (2011) 10:1 International Journal of Men’s Health 6 at 18.

Colleen Dell et al, "From Benzos to Berries: Treatment Offered at an Aboriginal Youth Solvent Abuse Treatment Centre Relays the Importance of Culture” (2011) 56:2 Canadian Journal of Psychiatry 75. Chassidy Pachula et al, "Using Traditional Spirituality to Reduce Domestic Violence Within Aboriginal Communities" (2010) 16:1 Journal of Alternative and Complementary Medicine 89.

Patrick Holland, Kevin Gorey \& Anne Lindsay, "Prevention of Mental Health and Behavior Problems Among Sexually Abused Aboriginal Children in Care” (2004) 21:2 Child and Adolescent Social Work Journal 109 at 113.

82 Louis Gliksman, Margaret Rylett \& Ronald R Douglas, “Aboriginal Community Alcohol Harm Reduction (ACAHRP) Project: A Vision for the Future” (2007) 42:12-13 Substance Use \& Misuse 1851. 
as health, education, and poverty. ${ }^{83}$ Martin's minority Liberal government was subsequently defeated, and replaced by a minority Tory Government led by Stephen Harper. Under the original Accord, \$600 million would have been spent during the 2006 fiscal year on the Accord's objectives. Harper's government, upon assuming power, replaced the Accord with a budgetary allocation of \$150 million during 2006 and \$300 million during 2007 to address similar objectives. ${ }^{84}$ Aboriginal peoples and their leaders have many times since decried this development as bad faith and neglect on the part of the federal government. ${ }^{85}$

The Aboriginal Healing Foundation was designed to provide programs to address the social legacies of colonialism, the residential schools in particular. The AHF has enjoyed some success in the pursuit of its mandate, as follows:

\footnotetext{
Impacts of the programs are reported as positive by the vast majority of respondents, with results ranging from increased self-esteem and pride; achievement of higher education and employment; to prevention of suicides.
}

\begin{abstract}
Reported community impacts are growth in social capital indicators such as volunteerism, informal caring networks, and cultural events. One of the notable impacts reported by case study communities is that the "silence" and shame surrounding IRS abuses are being broken, creating the climate for ongoing healing. Projects report that capacity for healing has been built in communities and between communities; an example of such inter-community capacity growth is the sharing of best practices that has occurred between communities in both formal and informal ways, supported by the AHF and undertaken by projects on their own. $^{86}$
\end{abstract}

The problem is that the AHF from the outset was only designed by the federal government as a short and brief initiative, and this is simply inadequate to undo the ongoing harm suffered by Aboriginal communities. The AHF explains further:

\begin{abstract}
Project reports show that healing program reporters identify an array of negative social indicators and challenges to healing that persist in their communities. Evaluation evidence from case studies shows that almost 90 percent of respondents estimate that "more than 50 percent" of their community members need healing from the effects of IRS. The estimated high level of need, together with the growing program enrolments and the anticipation that the Settlement Agreement processes will continue for at least another three years, support the argument for the continued relevance of AHF healing programs. The evaluation results strongly support the case for continued need for these programs, due to the complex needs and long term nature of the healing process. ${ }^{87}$
\end{abstract}

83 John Ibbitson, "In praise of a flawed native accord,” The Globe \& Mail (26 November 2005) A4.

84 Sue Bailey, “Tories gut Liberal-brokered \$5.1 billion in native funding,” The Toronto Star (3 May 2006) A6.

85 See e.g. Colin Perkel, "Fontaine calls on Ottawa to fulfill its responsibility to Aboriginals,” The Globe and Mail (13 October 2007) A7; Alison Auld \& Keith Doucette, “Aboriginal leaders call for more protests, days of action,” The Globe and Mail (11 July 2007) A8; “Ottawa's neglect invites Indian anger,” Toronto Star (20 May 2007) A16.

86 Aboriginal Healing Foundation, 2010 Annual Report (Ottawa: Aboriginal Healing Foundation, 2010), online: Aboriginal Healing Foundation <http://www.ahf.ca/downloads/annual-report-2010.pdf $>$ at 4, 7. 
It is obvious that the current government has a preference for spending far more resources on massive incarceration to deal with crimes after the fact, and by comparison minimal interest in investing in social programming that can address the root causes of many crimes. The annual budget for the federal prison system went from \$1.6 billion in the 2005-2006 fiscal year to $\$ 2.98$ billion for $2011-2012$. Much of that can be attributed to the Tory government's measures that include revoking two-for-one credit for interim custody, and amendments to section 752 of the Criminal Code that restricted the availability of conditional sentences for serious personal injury offences. ${ }^{88}$ Those costs are expected to increase even more with the recent passing of the omnibus crime bill that makes extensive uses of mandatory minimum prison terms for many offences. Ontario has estimated its yearly costs for corrections will increase by $\$ 1$ billion in order to accommodate the increased influx of inmates. Quebec estimates that its yearly costs will increase by $\$ 600$ million. Ministers of both provinces have publicly indicated that they are not willing to pick up the whole tab. ${ }^{89}$ To call such an approach "cost-ineffective” is being generous.

This discussion has salient relevance to the general problem of Aboriginal overincarceration, but it takes on a particularly illuminating relevance when it comes to Aboriginal DOs. As of 2011, there are a total of 458 DOs serving indeterminate terms, with roughly 120 of those being Aboriginal DOs based on the 26.4 percent percentage. If past research is any indication, most if not all of those will be in either maximum or medium security. ${ }^{90}$ A profile of dangerous offenders in 2002 found that 49 percent of DOs were initially classified as maximum security, 50 percent as medium security, and 1 percent as minimum security. ${ }^{91}$ If we assume the percentages from the 2002 study held true for the 120 Aboriginal DOs in 2011, and that half of them are in medium security, and the other half are in maximum security, the annual cost of keeping them in indeterminate detention would come to approximately $\$ 15,000,000$. That is quite a yearly demand on the budget, and this is before we even get into the costs of having prosecuted and imprisoned them for their prior offences leading up to the DO orders. Instead of making serious investments towards grave problems in Aboriginal communities, we continue to prioritize incarcerating Aboriginals having committed crimes. Canada pays far more in the long run as a result, and Aboriginal DOs represent the most damning indictment of this fact. Aboriginal peoples are born into conditions left behind by colonialism in which they will be inflicted with multiple traumas over lengthy periods of time, and thus it is no surprise that significant numbers of Aboriginal persons go on to become DOs. Much of this could be avoided if Canada was serious about addressing the plight of Aboriginal communities in any meaningful way, instead of overpaying over the long-term on account of Aboriginal over-incarceration generally, more specifically with Aboriginal DOs.

The concept of justice reinvestment as a policy undoubtedly has a great deal of relevance to the general problem of Aboriginal over-incarceration. What is unfortunately lacking is research that builds specific linkages between social criminogenic factors, the use of

Jeff Davis, "Prison costs soar 86\% in past five years: report,” National Post (18 July 2011).

Tobi Cohen, "Tories use majority to pass omnibus crime bill," National Post (12 March 2012).

Annual Report 2011, supra note 2 at 103.

Shelley Trevethan, Nicole Crutcher \& John-Patrick Moore, A Profile of Federal Offenders Designated as Dangerous Offenders or Serving Long-Term Supervision Orders (Ottawa: Research Branch, Correctional Service of Canada, 2002), online: Government of Canada Publications <http:// publications.gc.ca/site/eng/380353/publication.html> at 16-17. 
preventative programming to address those factors, and Canadian DOs. A research report produced by the CRC indicated that DOs had relatively higher needs than LTOs on various measures such as emotional, substance abuse, community functioning, attitude and employment. There is no explanation for how these needs areas were graded, no details or explanations on how DOs developed high needs, and no comparisons other than between DOs and LTOs. ${ }^{92}$

Matthew Yeager attempted to perform a critical criminological study based on qualitative interviews with over 100 DOs in Ontario. ${ }^{93}$ The questions were to ask convicts: "about their life histories, their experiences with the judiciary, and, importantly, their experiences with both the Correctional Service of Canada (our federal penitentiary service) and Canada's National Parole Board." ${ }^{44}$ He unfortunately had his research obstructed by government departments at multiple turns to the point that he had to abandon the project, and instead had to produce a dissertation based on a secondary literature review and three case studies of dangerous offender proceedings. ${ }^{95}$ The obstructive tactics included (among others) referring permission requests to another government department (for example, Parole Board to CRC), denials of Access to Information Act requests, suspension of visiting privileges to federal penitentiaries, the CRC issuing a new directive giving the CRC the right to review the contents of a study before its publication or release, and the subsequent use of that directive to deny permission to commence the original proposed study. ${ }^{96}$

It is frequently the case that we have to wait for a reported case before we get a sense of the DO's life history along with the criminogenic factors at play, and an appreciation of the need for much earlier intervention before criminal proceedings even begin. Two more case law examples reinforce this point. We read in $R$. v. Daniels:

Mr. Daniels told the psychologist that his mother had told him that she drank throughout her pregnancy and, as a result, there is a strong possibility that his cognitive development may have been affected by her drinking while he was in utero. Unfortunately, Mr. Daniels was exposed to a significant amount of violence and substance abuse as a young child. Mr. Daniels grew up being close to no one and to this very day, still has no close emotional attachments to anyone.

When Mr. Daniels was around seven or eight years of age, he was placed at St. Michael's Residential School in Prince Albert. It is unclear as to whether he was apprehended by the Department of Social Services or was placed there by his grandparents.

Mr. Daniels testified that when he was seven or eight years of age, he was caught shoplifting. He was brought back to the residential school by the R.C.M.P. He testified that he was disciplined by being stripped naked and beaten with a steel brush on his buttock until blood was drawn. ${ }^{97}$

$92 \quad$ Ibid at 26

93 Matthew G Yeager, "Getting the Usual Treatment: Research Censorship and the Dangerous Offender" (2008) 11:4 Contemporary Justice Review 413 at 415 [Yeager, “Usual Treatment”].

$94 \quad$ Ibid at para 415.

95 Ibid at 416-24; Matthew G Yeager, Constructing the Dangerous Offender: A Test of Quinney’s Social Reality of Crime (Doctorate of Philosophy Thesis: University of Carleton - Department of Sociology and Anthropology, 2007).

$96 \quad$ Yeager, “Usual Treatment," ibid at 416-21.

$97 \quad R v$ Daniels, 2008 SKQB 349, 321 Sask R 40 at paras 10-12 [Daniels]. 
And we read again in FR:

\begin{abstract}
Mr. Redwood is thirty-two years of age. He has amassed a criminal record consisting of forty previous convictions, many of which were for violent offences, although ten convictions were for mischief. He is the youngest of eleven children. He observed violence between his parents and did not have a good relationship with his father. He has reported that he was physically abused by his father and by his siblings. His mother was, and is, his primary support within the family. However, his mother has acknowledged that she was busy raising some of her grandchildren when he was a child and that he may have been neglected as a result.
\end{abstract}

Mr. Redwood was placed in the Lebret Residential School when he was eight years of age for eight months, during which time he was subjected to physical and sexual abuse. Following the family's move to Regina, he suffered racially based bullying at school, had few friends and often was involved in fights. His school attendance was poor and ended early. He achieved his Grade 9 at the age of twenty, while he was in the penitentiary. ${ }^{98}$

There is a lack of research that explicitly draws the linkages, as previously mentioned. At the same time, when one reviews the information that is available from various sources, adding things together and coming up with the natural conclusion is not difficult.

Aboriginal DOs signal to us that we need to give serious consideration to the whole concept of justice reinvestment as a policy, that we may need to pay more now to save later. We need to invest in healthier Aboriginal communities, otherwise we can only expect Aboriginal over-incarceration to persist along with a steady influx of Aboriginal persons who will designated as DOs after sustaining massive damage from their formative years onwards. But what about those who are already DOs now serving indeterminate terms, and those who will be on their way shortly and facing DO hearings?

\title{
V. RisK ASSESSMENT IN DANGEROUS OFFENDER HEARINGS
}

The fundamental tension that always threads the criminal law is the tension between protecting the public from crime and ensuring the fair and humane treatment of the accused. There is perhaps nowhere where this tension is more acute than when it comes to the whole issue of preventative detention. If the law fails to incapacitate an individual who gave indications of potential danger who then goes on to harm more people, then the justice system fails its mandate to protect the public. On the other hand, there is the competing concern of subjecting someone to indefinite detention on the basis of future crimes yet to be committed, but whose potential risk could be managed short of calling upon such an extreme measure.

As many who are subjected to preventative detention hearings have histories of sexual offences (Aboriginal DOs included), Amy Lageman writes:

Sexual offences are horrible crimes, more horrible than any other. They leave the victims forever changed, rob society of its feeling of safety, and cause children to grow up in fear. The perpetrators of this violence deserve to be punished and punished in accordance with the gravity of their crimes. They do not deserve, 
however, to have their civil rights violated wholesale. For while it may satisfy a deep-seated need for vengeance to imprison them forever or to effectively cage them within the community like animals, this cannot be the final solution. To implement measures such as those proposed is to do a larger disservice to society. A better future, one free of fear, cannot be created when the best solution to sexual crime is to "lock them up and throw away the key."99

As one could expect, the critical question in hearings to determine whether an accused is to be designated as a DO or as a LTO is what risk that accused presents, and whether that risk can be managed in the community. The Canadian legal system strives to strike the right balance for that tension between protecting the public and treating the accused fairly by relying on risk assessment methods that hold out the hope of objectivity, and some measure of precision. This process is heavily reliant on expert witnesses who employ a number of risk assessment tools to evaluate the risk and its manageability. ${ }^{100}$ Two of the most common instruments used by the experts, and ones frequently lauded by courts, are the Static-99 tool, ${ }^{101}$ and the PCL-R. ${ }^{102}$

The majority of Canadian DOs, Aboriginal DOs included, have consistently been sexual offenders, ${ }^{103}$ so the reliance on Static-99 is not surprising. The scoring (coding) form for Static- $99^{104}$ is as follows:

\begin{tabular}{|c|c|c|c|}
\hline $\begin{array}{c}\text { Static-99R Coding } \\
\text { Form Question Number }\end{array}$ & Risk Factor & Codes & Score \\
\hline $\mathbf{1}$ & Age at release & Aged 18 to 34.9 & 1 \\
& & Aged 35 to 39.9 & 0 \\
& & Aged 40 to 59.9 & -1 \\
& & Aged 60 or older & -3 \\
\hline \multirow{2}{*}{$\mathbf{2}$} & Ever Lived With & Ever lived with conjugal & \\
& & partner for at least two years? & 1 \\
& & Yes & \\
\hline \multirow{2}{*}{3} & Index non-sexual violence - & No & 1 \\
\hline \multirow{2}{*}{$\mathbf{4}$} & Any Convictions & No & 0 \\
& Prior non-sexual violence - & Yes & 1 \\
\hline
\end{tabular}

Amy Lageman, "Dangerous Offender Legislation: A Short Term Solution to a Long Term Problem” (1997-1998) 16:1 Dick J Int’l L 203 at 225-26.

EM Coles \& FE Grant, "The Role of the Expert Witness in Canadian Dangerous Offender Hearings” (1999) 6:1 Psychiatry, Psychology and Law 13.

$R v$ Natomagan, 2010 SKPC 7, 349 Sask R 161 at paras 26, 35.

$R v J M D, 2005$ QCCQ 18427; $R$ v Cook, 2010 MBQB 237, 259 Man R (2d) 109 at para 119; ibid at paras 26, 35.

James Bonta et al, The Crown Files Research Project: A Study of Dangerous Offenders (Ottawa, Ontario: Solicitor General of Canada, 1996).

“Static-99 Coding Form," online: Static.99 Clearing House <http://www.static99.org/pdfdocs/static99rcodingform.pdf $>$. 


\begin{tabular}{|c|c|c|c|c|}
\hline $\begin{array}{c}\text { Static-99R Coding } \\
\text { Form Question Number }\end{array}$ & Risk Factor & \multicolumn{2}{|c|}{ Codes } & Score \\
\hline 5 & Prior Sex Offences & $\begin{array}{c}\text { Charges } \\
0 \\
1,2 \\
3-5 \\
6+\end{array}$ & $\begin{array}{c}\text { Convictions } \\
0 \\
1 \\
2,3 \\
4+\end{array}$ & $\begin{array}{l}0 \\
1 \\
2 \\
3\end{array}$ \\
\hline 6 & $\begin{array}{l}\text { Prior sentencing dates } \\
\text { (excluding index) }\end{array}$ & \multicolumn{2}{|c|}{$\begin{array}{l}3 \text { or less } \\
4 \text { or more }\end{array}$} & $\begin{array}{l}0 \\
1\end{array}$ \\
\hline 7 & $\begin{array}{l}\text { Any convictions for non- } \\
\text { contact sex offences }\end{array}$ & \multicolumn{2}{|c|}{$\begin{array}{l}\text { No } \\
\text { Yes }\end{array}$} & $\begin{array}{l}0 \\
1\end{array}$ \\
\hline 8 & Any Unrelated Victims & \multicolumn{2}{|c|}{$\begin{array}{l}\text { No } \\
\text { Yes }\end{array}$} & $\begin{array}{l}0 \\
1\end{array}$ \\
\hline 9 & Any Stranger Victims & \multicolumn{2}{|c|}{$\begin{array}{l}\text { No } \\
\text { Yes }\end{array}$} & $\begin{array}{l}0 \\
1\end{array}$ \\
\hline 10 & Any Male Victims & \multicolumn{2}{|c|}{$\begin{array}{l}\text { No } \\
\text { Yes }\end{array}$} & $\begin{array}{l}0 \\
1\end{array}$ \\
\hline Tot & ore & \multicolumn{2}{|c|}{$\begin{array}{l}\text { Add up scores from } \\
\text { individual risk factors }\end{array}$} & \\
\hline
\end{tabular}

As one can see, the Static-99 is almost completely reliant on variables involving past sexual misconduct, with age and past relationships being the other two variables. A past criminal history that includes sexual offences frequently assures a significant Static-99 score for an accused facing a DO hearing.

The 20 items on the PCL-R list are as follows:

- $\quad$ glib and superficial charm

- $\quad$ grandiose (exaggeratedly high) estimation of self

- $\quad$ need for stimulation

- $\quad$ pathological lying

- $\quad$ cunning and manipulativeness

- $\quad$ lack of remorse or guilt

- $\quad$ shallow affect (superficial emotional responsiveness)

- $\quad$ callousness and lack of empathy

- $\quad$ parasitic lifestyle

- $\quad$ poor behavioral controls

- $\quad$ sexual promiscuity

- $\quad$ early behavior problems

- $\quad$ lack of realistic long-term goals

- $\quad$ impulsivity

- $\quad$ irresponsibility

- $\quad$ failure to accept responsibility for own actions

- many short-term marital relationships

- $\quad$ juvenile delinquency 
- $\quad$ revocation of conditional release ${ }^{105}$

Caleb Lloyd and others note that those who score higher on PCL-R tend to be designated as DOs more often than as LTOs. ${ }^{106}$ They also note that in DO cases, Crown and defence expert witnesses were frequently within three points of each other on PCL-R. ${ }^{107}$ Furthermore, in 71 percent of the cases they reviewed, both Crown and defence experts agreed that the accused was a risk to re-offend violently. ${ }^{108}$

And indeed, most of the reported cases that will be considered in this article see the Crown and defence experts alike agree that the accused was a risk to re-offend after their initial application of the risk assessment instruments. Sometimes their precise results varied, although the variance was usually not considerable. The much more fundamental point of contention between Crown and defence experts was usually whether the risk could be managed as part of an LTO order or whether it necessitated a DO designation. This should not be surprising as the standard risk assessments emphasize static factors in the form of past behaviour, but offer little in the way of assessing whether the risk can be managed through future rehabilitative programming and behavioural progress (more on this later).

What follows now is an overview of all reported cases available at the time of writing (from either CanLII or Quicklaw) where an Aboriginal accused was subjected to a DO determination, and where either PCL-R or Static-99 was used during the determination, and where the central issue was whether the accused's risk could be managed as a part of an LTO order instead. This is to say that nearly all of the available reported cases where an Aboriginal accused was facing a DO determination were considered in this article (54 in total). Judges and expert witnesses from the appropriate disciplines are apt to arrive at varying conclusions in any given case, especially on the contentious issue of whether the risk can be managed in the community. It is therefore not surprising that the results in reported cases on DO hearings have to a degree been all over the map. Nonetheless, certain themes emerge from this overview of the case law, with the overarching theme that courts have for the most part been inclined to exercise caution in favour of public safety. This holds true even when courts are made aware of LTO supervisory possibilities that are grounded in Aboriginal cultures that could provide more effective alternatives to standard supervisory programming. This raises serious concerns about whether a consideration of Gladue factors and Aboriginal alternatives are being marginalized by courts during DO hearings, contrary to the direction given in Ladue.

\section{A. Reasonable Doubt in Favour of A LONG Term OFFENDER}

There are some cases where courts have been willing to make LTO orders instead of DO orders. In R. v. J.N.J., the Crown expert, Dr. Lawson, utilized several risk assessments, 
including PCL-R, Static-99, the Minnesota Sex Offender Screening Tool, and SVR-20. ${ }^{109}$ The tests came up with varying results, with the PCL-R scoring lower, while the Minnesota tool and Static-99 tool scored relatively higher. Dr. Lawson acknowledged that the accused had made progress in a sex offender treatment program. He nonetheless stressed that the accused was a high risk to re-offend on the basis of actuarial instruments that stressed static rather than dynamic factors. ${ }^{110}$ Experts for the accused concluded that there was hope for eventual release into the community if there was long term programming that involved oneon-one therapy. This, along with the accused's recent progress, convinced Justice Ralph to designate the accused as an LTO. ${ }^{111}$

In R. v. Hall, the Crown expert witness, Dr. Stanley Semrau, used the SRV 20 actuarial tool to assess the accused's risk of sexual re-offending. Dr. Semrau concluded that the accused was a significant risk to re-offend, but that risk could be managed by a prolonged and intense program of treatment and supervision. This was sufficient to convince Justice Chamberlist to designate the accused as an LTO. ${ }^{112}$

In $R$. v. Sainnanap, the experts for the Crown and the defence each made an assessment using the Violent Risk Assessment Guide, which incorporates PCL-R. The defence expert came up with a significantly lower risk on PCL-R, and yet both experts came up with similar scores on the VRAG. Justice Kozak of the Ontario Supreme Court was ultimately persuaded that there was a realistic potential for LTO supervision because of the accused's expressions of remorse and willingness to accept responsibility. ${ }^{113}$

In R. v. I.N.H., the court appointed expert, Dr. Nicholaichuk, made a guarded conclusion that long-term supervision was possible for the accused, in part because he acknowledged that the accused had not previously undergone any sustained correctional treatment due to the prior sentences having been short stints in provincial jails. ${ }^{114}$ This convinced Justice Hrabinsky to designate the accused as an LTO. ${ }^{115}$ Likewise, in R. v. W.T., the court appointed expert ranked the accused high on the Static-99 scale, but expressed the opinion that the risk could be managed with intensive supervision and treatment directed to the accused's Fetal Alcohol Syndrome. ${ }^{116}$ In this case, Justice Hrabinsky was thus also convinced to go with an LTO order. ${ }^{117}$

In $R$. v. Pelkey, Justice MacAulay noted that the accused had made some progress in learning to avoid violent confrontations, but was still a risk to become violent while in an environment that involved alcohol. Justice MacAulay was willing to make an LTO order on the basis that the accused was now motivated to make full use of rehabilitative programming for the sentence he would have to serve for manslaughter. ${ }^{118}$ In $R$. v. Paibomsai, experts for 257,185 OAC 319 at para 29.

Ibid.

Ibid at para 92-93.

$R v$ Hill, 2002 BCSC 336, [2002] BCJ no 1166 (QL).

$R v$ Sainnanap (2004), OJ no 3826 (QL), [2004] OTC 811 (SC).

$R v I N H, 2004$ SKQB 402, [2004] SJ no 598 (QL).

Ibid at para 14.

$R v W T, 2004$ SKQB 418, 255 Sask R 132.

Ibid at para 21.

R v Perkley, 2012 BCSC 815 [2012] BCJ no 1119 (QL). 
both Crown and defence concluded that there was a reasonable possibility of eventual control. Justice O’Neill was thus willing to make an LTO order. ${ }^{119}$

In $R$. v. Yellowknee, Justice Walter was willing to grant an LTO order because all the Crown expert witnesses conceded that there was a possibility of eventual control, although it was not feasible until a much longer period of time had elapsed when the accused would be much older and his violent tendencies could be reduced. However, the sentence for the accused's vehicular homicide offence was at least 20 years, which helped tip Justice Walter in favour of the LTO order. ${ }^{120}$

In $R$. v. Roberts, the court appointed expert, Dr. Holden, concluded that the accused was an extremely high risk to re-offend and was pessimistic about being able to complete rehabilitation. Dr. Holden nonetheless concluded that rehabilitation remained an open possibility, since the accused had not previously completed any treatment programs. Justice Gabrielson was thus willing to make an LTO order. ${ }^{121}$

R. v. Nowdlak represents perhaps an interesting application of the proof beyond a reasonable doubt standard. The Crown expert scored the accused high on PCL-R and was of the opinion there was no reasonable prospect for control. Justice Johnson was nonetheless willing to designate the accused as a long-term offender, despite the fact that the defence expert had not had an adequate opportunity to assess the accused. ${ }^{122}$

In R. v. Bear, the Crown expert, Dr. Holden, concluded that the accused was an untreatable psychopath who would not respond to any supervision or treatment. The defence expert, Dr. Nicholachuik, concluded that the accused was treatable but with long-term and intense supervision. Justice Carter expressed a lack of surprise that the experts came to different conclusions, and felt that both experts approached the task with a certain bias. Justice Carter nonetheless decided to grant an LTO order, on the basis that the accused's learning disability explained his failures at completing previous correctional programming and spoke to the possibility of managing his risk. ${ }^{123}$

The law requires the Crown to prove beyond a reasonable doubt that the accused's risk cannot be managed under an LTO. The cases described above indicate that at least some judges try to uphold that standard. Even so, these cases also indicate that the defence had to provide a little something more to tip the judge in favour of an LTO. Examples included the accused demonstrating remorse, the Crown expert conceding the possibility of managing risk under an LTO, a court-appointed expert concluding that the risk could be managed under an LTO, or the accused not having access to programming during previous stints in jail. There are also factors that can tip a judge in favour of a DO order instead of an LTO order.

$120 \quad R v$ Yellowknee, 2008 ABPC 168, 445 AR 332. For another decision where the prospect of a lengthy initial sentence was enough to tip the judge in favour of an LTO, see $R v$ Baptiste, 2008 BCSC 1041, [2008] BCJ no 1577 (QL).

$121 \quad R v$ Roberts, 2007 SKQB 209, 300 Sask R 83.

$122 \quad R v$ Nowdlak, 2005 NUCJ 17, 66 WCB (2d) 17.

${ }_{123} \quad R v$ Bear, 2006 SKPC 107, 294 Sask R 58. 


\section{B. FACTORS IN FAVOUR OF A DANGEROUS OFFENDER ORDER}

There are a good many more cases where judges are willing to make the DO order. A quite frequent scenario is where the experts agree that there is a present risk to re-offend, but divide sharply on the degree to which that risk can be managed. Judges will therefore frequently look for various factors to break the deadlock. A frequent one is the degree to which the accused has or has not accepted personal responsibility for the harm caused. ${ }^{124}$ In $R$. v. Peters, Justice Clancy acknowledged that Gladue was potentially applicable to DO hearings. Justice Clancy ultimately concluded, in reliance on the Crown expert's evidence based on a PCL-R determination, that the accused's lack of remorse or willingness to accept responsibility, as well as the gravity and experience for his past record of violence, meant that there was no basis on which to treat the accused differently from other non-Aboriginal accused facing a DO determination. ${ }^{125}$ Justice Clancy also noted that the accused had a lack of connection to Aboriginal culture and that the accused's home community did not want him to return to his reserve, as additional factors in support of his conclusion. ${ }^{126}$

In R. v. Nome, Justice Gunn declared the accused a DO because his lack of motivation, as well as a very prolonged and extensive history of violence, both within and without prison, meant that there was no reasonable possibility of control. ${ }^{127}$ In R. v. Dillon, a high PCL-R list score coupled with refusals to accept responsibility and minimization of the harm caused led to a DO order. ${ }^{128}$

Another factor is failures by the accused to mollify behaviour in response to past programming, or a history of disobeying prior court orders. In R. v. Peters, Justice Smith disagreed with a joint submission for LTO supervision and instead designated the accused as a DO. Her reasons included his past failures to complete standard correctional programming, both experts having recommended against long-term supervision, and his apparent lack of remorse as well as behaving in a threatening manner towards witnesses at his trial. ${ }^{129}$ In R. v. Atitise, Justice Bryk of the Manitoba Court of Queen's Bench was unwilling to grant an LTO order. This was in part because the accused had already been through Aboriginal-specific programming in the past and in part because the accused had not even sought any programming for sexual offending or alcoholism during his previous term of incarceration. This convinced Justice Bryk that the accused was only giving lip service to wanting to change. ${ }^{130}$

In R. v. Lavallee, the Crown experts concluded that there was no reasonable prospect of long-term control. The defence expert concluded that the accused's behavior stemmed from traumatic brain injuries that left lasting damage, and that the accused's risk could be managed through a long-term program that cut the accused off from alcohol. ${ }^{131}$ Justice Mills concluded that any hope in an LTO order as an effective alternative was speculative, as there was a lack 
of community and family support that could provide an assurance of dealing with the accused's substance abuse problems that were underlying his behaviour. ${ }^{132}$

In $R$. v. Radcliffe, both experts agreed that the accused was a high risk to re-offend and that the probability of long-term risk management was low. ${ }^{133}$ The defence's expert suggested that there might be a possibility of control if the accused could stay with long-term and intensive supervision and medication. ${ }^{134}$ John Maracle, a Native Inmate Liason worker, testified that the accused was making progress and committing himself to changing after beginning participation in cultural ceremonies. ${ }^{135}$ Justice LaLonde made a DO order, noting that the accused's past failures to maintain medication to keep his behaviour under control was fatal to any prospect of long-term control. ${ }^{136}$

In R. v. Standingwater, Justice Rothery of the Saskatchewan Court of Queen's Bench made a DO order even when both the Crown and defence experts concluded that there was a possibility of eventual control. This conclusion was based in part on the accused's history of disobeying court orders, including prohibitions against stalking a former partner. ${ }^{137}$

In Daniels, Dr. Nicholaichuk appeared as the sole court-appointed witness. He conceded that the accused was a certainty to expose himself to negative peer association and substance, and thus a very high risk to re-offend. ${ }^{138} \mathrm{He}$ concluded that there was no reasonable possibility of eventual control, noting that the accused continued to re-offend despite participating numerous times in standard programs. ${ }^{139}$ He did however ask the court to grant an LTO order for compassionate reasons, and that a DO order would turn into a life sentence. Justice Popescul disagreed and made a DO order. ${ }^{140}$

Sometimes concerns about expert witness credibility will suffice to break the deadlock for the judge. In R. v. N.J.M., Dr. Bradford scored the accused high on both PCL-R and Static99, and concluded that the accused had an anti-social personality disorder and sexual paraphilia that were untreatable. ${ }^{141}$ Justice MacLeod of the Ontario Superior Court of Justice placed great reliance on Dr. Bradford's testimony as an expert with plenty of prior experience. ${ }^{142}$ He did not find Dr. Satterberg for the defence to be credible, concluding that Dr. Satterberg deliberately omitted several prior assessments and reports concerning the accused that should have elevated Dr. Satterberg's Static-99 scoring. ${ }^{143}$ He did not find Dr. Gojer to be credible, because Dr. Gojer based his assessments on information provided directly by the accused and thus was rendered suspect. ${ }^{144}$ Justice MacLeod thus had little trouble making a DO order. ${ }^{145}$

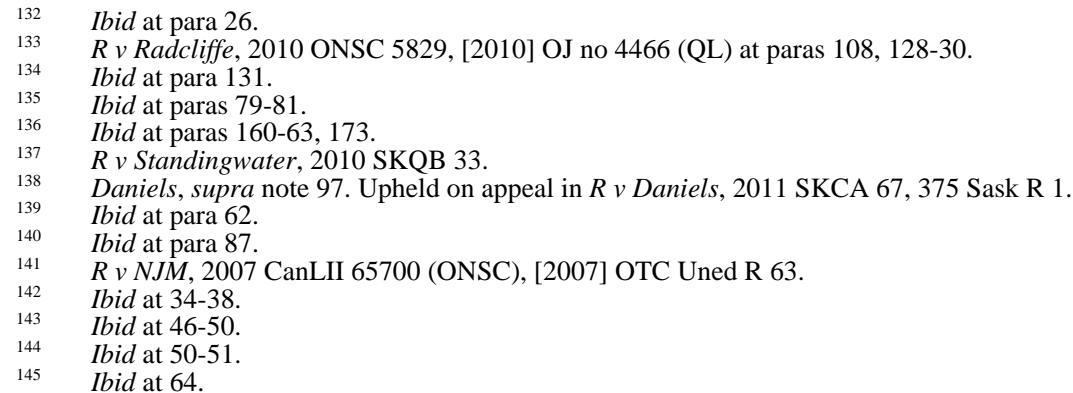


In R. v. L.F.A., Justice Whelan was concerned about the reliability and credibility of the Crown expert, who had prior access to a Crown summary that contained unproven allegations, or prosecutions where a stay was entered. ${ }^{146}$ Justice Whelan was concerned that Crown expert evidence was based on unreliable information, and thus gave greater weight to the defence expert evidence in making an LTO order. ${ }^{147}$

Sometimes there are factors present in a case that can tip a judge in favour of a DO order. Some of them stem from the accused himself, such as a lack of remorse, not accepting personal responsibility, lack of motivation, failure to complete prior programming, and disobedience of previous court conditions. Others stem from the outcomes of adversarial advocacy, such as a credibility problem with the defence expert. There are, however, a significant number of cases where such factors are not clearly present to tip the judge either way. These cases are particularly concerning in that they raise questions about whether the judges are applying the appropriate legal standards.

\section{Avoidance of Risk to the Public}

Sometimes there are cases where everything else may be equal. There may not be anything in particular that provides a judge with a tangible foundation on which to choose one expert's testimony over the other. A noticeable trend in many of these cases is that judges will make a DO order instead of a LTO order as a caution in favour of public safety, perhaps to the point that the Crown has been relieved of its burden to prove the inadequacy of an LTO order beyond a reasonable doubt. In $R$. v. Poole, the accused had a history of violence while intoxicated. Both experts agreed that he was not dangerous so long as he abstained from alcohol. The Crown expert, Dr. Semrau, concluded that any supervision plan had no realistic possibility because he had a lengthy history of drinking alcohol at the first opportunity while under probation or supervision. The defence expert, Dr. Perry, held that it was possible as long as a very stringent LTO plan was put in place, pursuant to an LTO order. Justice Collver gave a DO order, stating that he was not going to gamble with public safety. ${ }^{148}$

In $R$. v. Smaamslet, the accused had an especially egregious history of violence that included physically and sexually abusing women in relationships, and murdering a woman while on bail for another violent offence against a woman. ${ }^{149}$ Dr. Tomita held that the accused rated high on PCL-R, and was untreatable. Even the defence expert, Dr. Nicholaichuk, held out that there was a possibility of long-term control but conceded that it was a vague uncertainty, along the lines of “we don't know.” Justice Loo of the British Columbia Supreme Court had little trouble finding the accused a DO. ${ }^{150}$

In $R$. v. Corbier, the defence expert concluded that the accused, a serial pedophile, was treatable under a pilot project, Circles of Support, located in Ontario. ${ }^{151}$ The Crown expert witnesses had however found that the accused scored high on tools like Static-99 and VRAG.

$R v L F A, 2007$ SKPC 63, 298 Sask R 1.

Ibid at paras $179-80,187$.

$R v$ Poole, 2000 BCCA 481, 142 BCAC 151 at paras 8-11.

$R v$ Smaaslet, 2007 BCSC 504, 73 WCB (2d) 201 at paras 2, 168.

Ibid at paras 3, 5, 190-91.

$R v$ Corbier, 2007 ONJ 712, 2008 CarswellOnt 9505 (WL Can). 
Justice Main found that the possibility of long-term supervision "remote, speculative, and premature," and thus granted the DO order. ${ }^{152}$

In R. v. Stonechild, both Crown and defence experts scored the accused high on PCL-R, and on Static-99, as well as others. It was also noted that the accused did not avail himself of the opportunity to participate in treatment, including programs designed specifically for Aboriginal sexual offenders. The Crown expert, Dr. Semrau, concluded that there was no reasonable possibility of eventual control. The defence expert, Dr. Wormith, also expressed reservations about the accused's willingness to accept responsibility. The most Dr. Wormith was willing to say was that the accused had not previously had the opportunity for long-term supervision in his community, and instead always went on to re-offend after previous stints in prison. Justice Dawson of the Saskatchewan Court of Queen's Bench found that this would amount to placing faith in a dubious hypothetical, and designated the accused a DO. ${ }^{153}$

If the reported cases are any indication, it would seem that accused facing DO hearings, Aboriginal accused included, face a daunting task. The legal burden is on the Crown to establish beyond a reasonable doubt a serious personal injury offense, a pattern of behaviour indicating a likelihood of future harm, and that the risk cannot reasonably managed by an LTO order. It could be suggested that once the first two requirements are proven, a practical (if not legal) burden shifts onto the accused to prove that the risk can be reasonably managed by an LTO. Decisions that are tilted by concerns like expert witness credibility and a past history for disregarding court orders are easy enough to understand. What is potentially concerning are decisions that, when everything else may be equal, still evidence a preference for DO orders over LTO orders as a caution in favour of public safety. This may raise questions about whether adequate consideration is being given to whether the LTO suffices to protect the public instead of an DO. This trajectory also seems to manifest when defence lawyers assert Aboriginal alternatives to standard supervision and programming.

\section{Aboriginal Alternatives AcCePted}

The idea here is that programming, not just standard programming but programming that also includes Aboriginal cultural elements, may provide effective alternatives for purposes of an LTO supervision plan. Dr. Koopman emphasized the need for such alternatives as an expert witness in R. v. M.(R.T.), as follows:

\footnotetext{
Aboriginal incest offenders tend to have overwhelming unmet emotional needs as compared with nonaboriginal incest offenders who usually have jobs, status, and community recognition and support at the same time as they are incestuously offending. Aboriginal inter-generational incest offenders rarely have this compartmentalized “island of offending” pattern. Their lives tend to be pervasively dysfunctional beginning with their abusive childhood and eventuating as adults in grinding poverty, unemployment, substance abuse, family violence, lack of validation and support, low self-esteem, no positive view for a future, hopelessness and desperation. The programs offered to them within the prison system, including one-to-one counselling, usually do not deal with the nature and breadth of the problems that these offenders suffer. This can also be
}

$153 \quad R v$ Stonechild, 2008 SKQB 98, 312 Sask R 86. See also $R v$ Montgrand, 2011 SKQB 14, 367 Sask R 270. 
true of some of the sex offender programs required of the offender in the community as a condition of release.

Programs for sex offenders, as usually delivered, tend to be non-specific with regard to the type of sexual offence perpetrated. They also do not usually provide specific content or treatment for aboriginal offenders and particularly do not provide for aboriginal inter-generational incest offenders. Relapse plans and maintenance plans developed in prison often do not have a community follow up with a local relapse plan and support system in place. ${ }^{154}$

This argument has been advanced by defence lawyers during DO hearings with occasional success. Dr. Koopman stressed that the accused needed culturally sensitive programming as the best chance of dealing with his problems and managing the risk. Justice McEwan of the British Columbia Supreme Court agreed and designated the accused as a long-term offender. ${ }^{155}$ In R. v. R.B.P., the Crown expert scored the accused high on PCL-R, and the Static-99 and VRAG tools. The Crown expert thus concluded that the accused suffered from an anti-social personality disorder that left no reasonable prospect of supervised release. The defence expert acknowledged that the accused if left unsupervised was a high risk to reoffend, but also emphasized that the accused began to accept responsibility, and started spiritual mentoring under Aboriginal elders. Justice LaLande agreed and found that a reasonable doubt was raised so as to make an LTO order. ${ }^{156}$

In R. v. M.A.G., the Aboriginal accused had committed a series of violent assaults, the last one being where he stabbed somebody else in the torso and penetrated the victim's liver. The Crown expert, Dr. Holden, saw little possibility of eventual control, based on high scores on both HCR-20 and PCL-R. Dr. Holden, however, ultimately concluded that the accused should be given a chance at LTO. The defence expert, as well as Aboriginal elders from the community, held out that intensive supervision and treatment combined with community supports guided by the elders could turn him around. Justice Chicoine thus agreed to grant an LTO order. ${ }^{157}$

An interesting case is $R$. v. Keller, where the evidence was equivocal on whether the accused was truly motivated to change. The Crown expert noted his lack of desire to upgrade his education or attain ongoing employment, as well as a tendency to blame others for his problems. The defence expert emphasized that the accused did display improved behaviour while serving a previous prison term after having completed an Aboriginal-specific program. Justice Konkin of the Saskatchewan Court of Queen's Bench placed emphasis on Gladue in order to designate the accused as an LTO. ${ }^{158}$ 


\section{E. Aboriginal Alternatives Marginalized}

These cases do, however, appear to be in the clear minority when arguments for Aboriginal-based alternatives are emphasized. There are significantly more cases where such arguments have not persuaded courts. In F.R., the Crown expert held on the basis of PCL-R and other tests that the accused was an untreatable psychopath who would not respond to any supervision or treatment. The defence expert held that long-term supervision and treatment was possible if a program that included Aboriginal culture and spirituality could manage the accused's substance addictions. The tie was broken when the court-appointed expert witness sided with the Crown expert, convincing Justice Snell of the Saskatchewan Provincial Court to designate the accused as a DO. ${ }^{159}$

In R. v. Pascal, the Crown expert, Dr. Klassen, rated the accused very high on both PCL-R and Static-99 and was therefore an untreatable psychopath. ${ }^{160}$ Justice Platana of the Ontario Superior Court of Justice noted:

\footnotetext{
Dr. Klassen was asked in examination-in-chief whether he paid any recognition to the fact that Mr. Pascal is Aboriginal. He acknowledged that he did and indicated that there are no specific data sets for Aboriginals. He did express his view, however, that there is no reason not to use the same data for Aboriginal offenders. He did agree that the PCL-R, the SORAG, the STATIC-99, and the HCR-20 have not been subjected to a specific evaluation as to whether the results are good, better, or worse in Aboriginals than in nonAboriginals. ${ }^{161}$
}

And again with this concession:

Further in cross-examination Dr. Klassen acknowledged that if there were programs specifically designed for Aboriginal individuals with crime and violence, sexual offences and substance abuse issues that have healing in them, that may have an effect in the outcome in minimizing Mr. Pascal's risk to the community. ${ }^{162}$

Justice Platana nonetheless found that there was no reasonable possibility of control based on the accused's failure to modify behaviour in response to standard programming, and deemed the accused a DO. ${ }^{163}$

This trend also includes cases where Aboriginal community members express a willingness to sponsor the accused in his recovery, or where the accused has personally made progress with behaviour. In R. v. C.M.M., Dr. Darlington and an Aboriginal Elder testified in their belief that if the accused underwent long-term treatment for his alcohol abuse, his risk for reoffending could be effectively managed. One of the Elders, Stewart Prosper, told the court that he would not have testified if he was not convinced that the accused was committed to changing. Dr. Levin, for the Crown, was of the view that the accused's series of rapes and attempted rapes was attributable to an anti-social personality disorder and that he was a certain and ongoing risk for sexual re-offending. Justice Krueger was satisfied

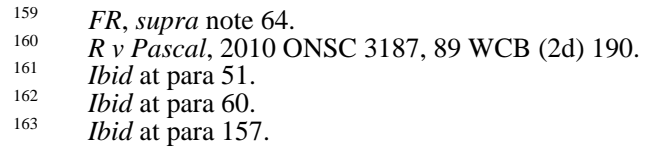


beyond a reasonable doubt that the accused was incapable of controlling his sexual urges, and that he was not committed to changing. ${ }^{164}$

In R. v. G.C., two Aboriginal Elders testified that the accused, who had engaged in a series of sexual assaults with a weapon, had started to make progress with his underlying alcoholism and other behaviorial problems by participating in Aboriginal ceremonies and acknowledging responsibility for his actions. The accused has previously tried to enter alcohol treatment programs, but only in a brief and superficial sense. The court also relied on a single court appointed witness, Dr. Nicholaichuk, to provide an opinion to the court. Dr. Nicholaichuk assessed the accused as a high-risk to re-offend, but conceded that long term treatment and supervision to manage the risk were possible. ${ }^{165}$ Justice Gerein nonetheless designated the accused as a DO and dismissed the accused's recent efforts as "too little too late.”166 Justice Barclay of the Saskatchewan Court of Queen's Bench dismissed Dr. Wormith's assertion that the accused was availing himself of community supports and Elders' counselling in $R$. v. Ewenin, as the accused's lengthy history of not complying with court orders rendered Dr. Wormith’s assertion mere "hope or empty conjecture.”167

In R. v. Brass, Dr. Nicholaichuk testified that the accused's risk to re-offend could be managed through Aboriginal-specific programming and guidance by Elders. This opinion was supported by a Band Councillor and addictions counsellor from the accused's community. The Saskatchewan Court of Appeal dismissed the value of this evidence on appeal on the basis that it was overly general, and depended on questionable assumptions that could not satisfy the need to protect the public. ${ }^{168}$

In Badger, a number of correctional officials testified that there were some culturallybased intensive programs that could help the accused with his behaviour. Members of the community, including Elders and spiritual healers, as well as his band and council, also extended their support for the accused to undergo long-term supervision and treatment. Dr. Wormith, as the sole court-appointed expert, also expressed the opinion that the accused was motivated to change his behaviour. Justice Zarzeczny nonetheless concluded, on the basis of the accused's past and numerous attempts at standard programming (for example, Alcoholics Anonymous), that the accused was not truly motivated to change, and issued a DO order. ${ }^{169}$

$R v$ CMM, 1997 CanLII 12397 (SKQB). See also R v CJD, 2012 SKQB 101, 391 Sask R 240.

$R \vee G C, 2001$ SKQB 2, 205 Sask R 161.

Ibid at para 108. See also $R v B R B, 2002$ BCCA 420, 2002 CLB 750.

$R v$ Ewenin, 2009 SKQB 207, 334 Sask R 61 at paras 141, 181-82. It is interesting to note that this case was successfully appealed to the Saskatchewan Court of Appeal in $R v$ Ewenin, 2013 SKCA 50, 414 Sask R 171. The point on which the appeal succeeded was not Justice Barclay's dismissal of a culturallyspecific supervision plan as "hope or empty conjecture.” The point on which the appeal succeeded was that Justice Barclay limited himself to considering whether the accused's determinate sentence was sufficient to manage the accused's risk, whereas he was required to consider whether both the determinate sentence and an LTO together sufficed to manage the risk. The Court of Appeal did not substitute an LTO order, but rather sent the matter back to the Saskatchewan Court of Queen’s Bench to have the application reconsidered as the Court of Appeal did not have a sufficient evidentiary record to decide the application. 
What is often fatal is when an accused has been through programming that included Aboriginal cultural elements, but went on to re-offend afterwards. In $R$. v. Wright, Justice Gunn of the Saskatchewan Court of Queen's Bench noted that the accused had both continued to commit crimes despite participating in culturally-based programs several times, and had offended while under an LTO order. Justice Gunn stressed that this did not automatically or categorically preclude the offender from being given another chance, and yet it was crucial in the decision to grant the DO order. ${ }^{170}$

In R. v. L.C.W., the accused engaged in a series of rapes, the last one occurring despite going through a number of rehabilitative programs. Some of these programs did include culturally sensitive components, like the New Dawn Valley Treatment Centre in Fort Qu'Appelle, Saskatchewan, and the Native Substance Abuse Program. Justice Barclay thus felt that there was no alternative but to designate the accused as a DO. ${ }^{171}$

In R. v. Laprise, an Aboriginal elder and a couple of psychiatric experts for the defence noted to Justice Wedge of the Saskatchewan Court of Queen's Bench that the accused, who had a history of violence against women he had been in relationships, had taken steps to address his behaviour through Aboriginal spirituality and culturally sensitive programming. One of those witnesses, Dr. Darlington, noted that the accused had a history of violence but that it was less than in other DO hearings that he had been an expert witness in, and often less than others who appear before the courts but are not facing dangerous offender applications. The expert witness for the Crown, Dr. Levin, asserted that the accused was a continuing danger. Justice Wedge found that in all of the evidence, a reasonable doubt was raised. ${ }^{172}$ The story does not end there though. The accused had gone on to commit 19 more offences, including a serious and violent sexual assault, since the first DO hearing. Judge White thus had little difficulty now designating the accused as fit for indeterminate detention. ${ }^{173}$

In R. v. Jamieson, Justice Bennett of the British Columbia Supreme Court found the accused to be a DO both because he scored high on the PCL-R, and also because he had previously completed culturally appropriate rehabilitative programs and yet continued to reoffend. ${ }^{174}$ Justice Bennett also noted, "Mr. Jamieson is an Aboriginal offender. Any sentence imposed must take into consideration the principles outlined in $R$. v. Gladue.... However, the mitigating effect of his upbringing, tragic as it was, on a sentence is tempered by the horrific and violent nature of his acts"175

It is now appropriate to quote this particular passage from Justice Cory in Gladue:

Section 718.2(e) requires the sentencing judge to explore reasonable alternatives to incarceration in the case of all aboriginal offenders. Obviously, if an aboriginal community has a program or tradition of alternative

\footnotetext{
$170 \quad R v$ Wright, 2008 SKQB 268, 317 Sask R 267 at paras 199-205.

$171 \quad R \vee L C W, 2000$ SKQB 302, 195 Sask R 1 at paras 1-15, 50, 74, 124, 136.

$172 \quad R$ v Laprise, (1997) 151 Sask R 276, 33 WCB (3) 470.

$173 \quad R v$ Laprise, 2005 SKPC 9, CLB 15703.

$174 \quad R$ v Jamieson, 2006 BCSC 1914, 71 WCB (2d) 911 [Jamieson]. See also $R v$ Brown, 200639 WCB (2d) 780, [2006] OJ no 1523 (QL). Jamieson, ibid at para 81 .
} 
sanctions, and support and supervision are available to the offender, it may be easier to find and impose an alternative sentence. $^{176}$

Justice Cory also adds that the absence of Aboriginal-specific programming will not preclude a consideration of a non-custodial sentence. ${ }^{177}$ Recall also that Ladue calls for a consideration of the Gladue factors when adjudicating DO applications. A court hearing a DO application must thus give a serious consideration of whether the availability of culturally appropriate programming that was previously unavailable to the accused merits granting an LTO order instead of an DO order. It is thus highly concerning when judges hear evidence of the availability of Aboriginal-specific programming and community supports that were not previously available to the accused, but then dismiss such evidence as 'questionable assumptions' or 'empty conjecture' and so on. Such a trend raises questions of whether the judges are marginalizing the availability of Aboriginal-based alternatives, contrary to legal principle.

There are of course cases where the accused did participate in cultural programming and went on to re-offend. These cases are admittedly concerning for reasons of public safety. At the same there is empirical evidence that people who re-offend while under LTO supervision are in the clear minority. The Correctional Service of Canada did a research analysis on all offenders who were released on LTO orders prior to August of 2010. The analysis found that only 12 percent of sexual offenders had their LTO orders revoked within a year without being charged with a new crime (for example, breach of an LTO order condition), and only 18 percent of offenders charged with other crimes. The rates were even lower for revocations of LTO orders within a year with the offender being charged with a new crime: 10 percent for sexual offenders and 14 percent for other offenders. ${ }^{178}$ It is perhaps a question of how best to structure LTO supervision plans for Aboriginal persons so as to minimize their risk of recidivism while on release. It is this subject that I now begin to explore.

\section{F. STANDARD Risk ASSESSMENT CoNTESTED}

It is also interesting to note a few cases where the expert witness for an Aboriginal accused explicitly questions the utility of standard instruments in assessing the risk posed by Aboriginal accused. In R. v. L.T.P., Dr. Lamba concluded on the basis of a high PCL-R score that there was no reasonable possibility of long-term supervision. Dr. Lohrasbe criticized PCL-R as a tool whose development testing samples did not include Aboriginal subjects, and was also inapplicable to someone who was left cognitively challenged by Fetal Alcohol Syndrome. Justice Bauman, relying in part on Dr. Lohrasbe's evidence but also on the accused's recent efforts to connect with family members, as well as the accused's good work habits during recent prison details, decided to designate the accused as an LTO. ${ }^{179}$

Gladue, supra note 16 at para 92.

Ibid at para 93.

Renée Gobeil, Offenders with Long-Term Supervision Orders: Comparing Rates of Return (Correctional Service of Canada, 2012), online: Correctional Service Canada <http://www.csc-scc.gc.ca/research/ research/005008-rs12-04-eng.shtml>.

$R v$ LTP, 2005 BCSC 97, 63 WCB (2) 491. See also $R v$ Peters, supra note 129 at para 75, where Dr Joseph Noone expressed the opinion that PCL-R was of questionable value when it came to Aboriginal offenders. 
In R. v. Ominayak, Dr. Choy, the Crown expert, ranked the accused 27 on PCL-R, as well as high on actuarial sex-offender tools. The defence expert, Leslie Block, scored the accused 20 on PCL-R. Mr. Block also emphasized that the accused had not previously had access to culturally-sensitive programming. He also criticized Dr. Choy's application of PCL-R as failing to take into consideration its limitations when addressing the special circumstances of Aboriginal persons. An Aboriginal elder, Errol Crier, also testified that culturally-sensitive treatment could help the accused. Justice Topolniski of the Alberta Court of Queen's Bench found that Dr. Choy was a credible and impartial witness, while dismissing Mr. Block's criticism of Dr. Choy's approach as biased advocacy. She thus made a DO order. ${ }^{180}$

Dr. Hengen, in R. v. L.M.W., advocated the use of an adult-education program that he had designed as the basis of an LTO plan, predicting that there would only be a 5 to 11 percent chance that the accused would reoffend. Justice Dovell of the Saskatchewan Court of Queen's Bench viewed Dr. Hengen's opinion as biased advocacy, both because the adult education program had not been tested by the Correctional Service of Canada, and because the statistical probability directly contradicted psychological assessments of the accused during his periods of incarceration. ${ }^{181}$ The idea of drawing upon Aboriginal specificprogramming to tip the scales in favour of LTOs has had some, but not a lot of, purchase with Canadian courts. This is perhaps unsurprising, as the disciplines from which the Court draws its expert witnesses for DO cases have not yet grappled with the issue.

\section{Risk AsSESSMENT FOR ABORIGINAL ACCUSED RECONSIDERED}

There may be some justification for the reliance on Static-99 and PCL-R for DO determinations. Some studies have found Static-99 to have predictive accuracy. ${ }^{182}$ Some studies have found PCL-R to be moderate to highly accurate in predicting future recidivism. ${ }^{183}$ Higher PCL-R scores have also been found to correlate with higher drop out rates from treatment programs. ${ }^{184}$ What is interesting to note is that both instruments place a premium on static predictors of risk, those tied with past misbehaviour, instead of dynamic predictors that emphasize current circumstances or progress with behaviour. One glance at the Static-99R Coding Form should make it obvious that it has a near exclusive focus on past behaviour as a predictor of recidivism risk. Grant Burt explains that PCL-R also has a static orientation, as follows:

$R v$ Ominayak, 2007 ABQB 442, 443 AR 1.

$R v L M W$, 2007 SKQB 265, 77 WCB (2d) 499 at para 110.

Jerome Endrass et al, “Accuracy of the Static-99 in Predicting Recidivism in Switzerland” (2009) 53:4 International Journal of Offender Therapy and Comparative Criminology 482; Eric Beauregard \& Tom Mieczkowski, "Testing the Predictive Utility of the Static-99: A Bayes Analysis” (2009) 14 Legal \& Criminalogical Psychology 187; Keith Soothill et al, "Identifying Future Repeat Danger from Sexual Offenders Against Children: a Focus on Those Convicted and Those Strongly Suspected of Such Crime" (2005) 16:2 Journal of Forensic Psychiatry and Psychology 225.

Ralph C Serin \& Nancy L Amos, "The Role of Psychopathy in the Assessment of Dangerousness" (1995) 18:2 International Journal of Law \& Psychiatry 231; Roope Tikkanen et al, "Psychopathy, PCLR, and MAOA Genotype as Predictors of Violent Reconvictions” (2011) 185:3 Psychiatry Research 382; Klaus-peter Dahle, "Strengths and Limitations of Actuarial Prediction of Criminal Reoffence in a German Prison Sample: a Comparative Study of Lsi-r, Hcr-20 and Pcl-r” (2006) 29:5 International Journal of Law \& Psychiatry 431.

Mark E Olver \& Steve Wong, "Predictors of Sex Offender Treatment Dropout: Psycopathy, Sex Offender Risk, and Responsivity Implications” (2011) 17:5 Psychology, Crime \& Law 457. 
Because the PCL-R is based on the measurement of stable global personality traits and enduring antisocial behaviors to distinguish effectively between low, medium and high risk offenders, it presents risk as stable and constant. In particular, considering that PCL-R ratings are based on an offender's life history, even dramatic changes in behavior during treatment would be unlikely to influence PCL-R ratings because of the relatively short time span of correctional treatment programs (i.e., 2 - 6 months).

The static approach used by the PCL-R is not surprising in that Hare (1996) has argued that the PCL-R was designed to assess a personality disorder, rather than to be used to predict violent recidivism. ${ }^{185}$

If many experts within mental health disciplines feel a certain confidence in relying on static predictors in assessing recidivism risk, it is one that is often shared by judges as well. In $R$. $v$. Wolfe, Justice Hunter of the Saskatchewan Court of Queen's Bench relied on the opinion of Dr. Vijay Singh to find the accused a Dangerous Offender. Justice Hunter in particular quoted with approval this passage from Dr. Singh’s report:

The single most predictor of future behaviour is one's past behaviour, it's nature, it's characteristic, and the way it was performed or done. There are vast amount of literatures on predicting future violence but this is what is the single most predictor which I rely upon, courts rely upon, so do other forensic psychiatrists. ${ }^{186}$

Overall, the available empirical evidence is actually equivocal on whether Static-99 and PCL-R can accurately gauge recidivism risk. A study using a sample of 394 adult Austrian sexual offenders could not find that Static-99, and a few other actuarial tools, have predictive accuracy for violent sexual re-offending. The study argues that this raises important questions about what role dynamic factors should have in the assessment of risk, and that further research is needed. ${ }^{187}$ A study by Niklas Långström found that Static-99 had high predictive accuracy for Nordic and non-Nordic Europeans, but no predictive accuracy for Blacks and Asians in Sweden. ${ }^{188}$ A meta-analysis of several empirical studies found that Static-99 had predictive accuracy of sexual re-offending for both Aboriginal and nonAboriginal sexual offenders. ${ }^{189}$

Another study of 138 offenders who dropped out of treatment found that a high PCL-R had no predictive value for dropping out. ${ }^{190}$ A study by Min Yang, Stephen C.P. Wong, and Jeremy Coid found that the personality components of PCL-R had no predictive accuracy,

Grant N Burt, Predicting Violent Recidivism of Treated Offenders Using the Psycopathy ChecklistRevised and the Violence Risk Scale (MA Thesis: University of Saskatchewan, Department of Psychology, 2011) at 10-11 [unpublished]. $R v$ Wolfe, 2001 SKQB 66, 202 Sask R 1 at paras 66, 99-100.

187 Martin Rettenberger et al, "Prospective Actuarial Risk Assessment: A Comparison of Five Risk Assessment Instruments if Different Sexual Offender Subtypes” (2010) 54:2 International Journal of Offender Therapy \& Comparative Criminology 169.

Niklas Långström, “Accuracy of Actuarial Procedures for Assessment of Sexual Offender Recidivism Risk May Vary Across Ethnicity” (2004) 16:2 Sexual Abuse: A Journal of Research and Treatment 107. Kelly M Babchishin, Julie Blais \& Leslie Helmus, "Do Static Risk Factors Predict Differently for Aboriginal Sex Offenders?: A Multi-site Comparison Using the Original and Revised Static-99 and Static-2002 Scales” (2012) 54:1 Canadian Journal of Criminology and Criminal Justice 1. 
but that the criminal history components did have predictive accuracy. ${ }^{191}$ A study that monitored recidivism among 1,353 offenders in England for a period averaging two years post release found that individual items on the PLC-R list had no predictive accuracy. ${ }^{192}$ Another study involving 156 Canadian federal inmates found that PCL-R was predictive of violent re-offending, but not of sexual re-offending. ${ }^{193}$

An evaluation of the Intensive Treatment Program for Sexual Offenders, offered by the Correctional Service of Canada, evaluated recidivism for 81 offenders. Offenders who were placed in care as a child were a greater risk for recidivism. Childhood sexual abuse was predictive of violent recidivism, but not sexual recidivism. Childhood physical abuse was predictive of violent recidivism. Higher scores on the PCL-R was not predictive of sexual recidivisim. ${ }^{194}$

At the heart of this issue is to what extent forensic risk assessment should stress static factors or dynamic factors, and opinions have varied on this subject. Moreover, the John Howard Society questions the reliance on static factors in assessing recidivism and encourages instead an emphasis on dynamic factors by corrections and parole officers:

Dynamic factors have been found to predict recidivism as well as, or better than, static factors ... and are also measured by several actuarial risk assessment tools. It is knowledge of dynamic factors that is necessary in order to assess changes in an offender's risk level.... Through participation in rehabilitative programming, an offender may become less likely to recidivate, but corrections and parole workers would not be able to measure this change unless they assessed the offender's risk based on changeable factors. ${ }^{195}$

Susan Bengston, however, cautions: "However, research has yet to determine how best to integrate dynamic risk factors into a comprehensive risk evaluation and whether changes in dynamic risk factors (stable or acute) actually reduce recidivism risk."”196

Notwithstanding Bengston's caution, evidence is starting to mount that programming that includes Aboriginal culture and spirituality can address the risk of recidivism for many Aboriginal accused. This in turn suggests that risk assessment for Aboriginal accused, including Aboriginal accused facing DO determinations, should place greater emphasis on dynamic factors (that is, present progress with behaviour). The "In Search Of Your Warrior"

Min Yang, Stephen CP Wong \& Jeremy Coid, “The Efficacy of Violence Prediction: A Meta-Analytic Comparison of Nine Risk Assessment Tools” (2010) 136:5 Psychological Bulletin 740. See also Patrick $\mathrm{H}$ Kennealy et al, "Do Core Interpersonal and Affective Traits of PCL-R Psychopathy Interact with Antisocial Behavior and Disinhibition to Predict Violence?” (2010) 22:3 Psychological Assessment 569. Jeremy Coid et al, "Most Items in Structured Risk Assessment Instruments Do Not Predict Violence" (2011) 22:1 Journal of Forensic Psychiatry \& Psychology 3.

193 Mark E Olver \& Stephen CP Wong, "Psychopathy, Sexual Deviance, and Recidivism Among Sexual Offenders” (2006) 18:1 Sexual Abuse: A Journal of Research and Treatment 65.

194 Anne Deitrich, W Carson Smiley \& Claire Frederick, "The Roles of Childhood Maltreatment and Psychopathy in Sexual Recidivism of Treated Sexual Offenders” (2007) 14:3 Journal of Aggression, Maltreatment \& Trauma 19.

195 Offender Risk Assessment (Edmonton: John Howard Society, 2000), online: John Howard Society <http://www.johnhoward.ab.ca> at 3. The studies being referred to are Paul Gendreau, Tracy Little \& Claire Goggin (1996), A Meta-Analysis of the Predictors of Adult Offender Recidivism: What Works! (Ottawa: Public Works and Government Services Canada, 1996); R Karl Hanson \& Monique T Bussière, Predictors of Sexual Offender Recidivism: A Meta-Analysis (Ottawa: Public Works and Government Services Canada, 1996).

196 Susanne Bengston, "Is Newer Better? A Cross-Validation of the Static-2002 and the Risk Matrix 2000 in a Danish Sample of Sexual Offenders” (2008) 14:2 Psychology, Crime \& Law 85 at 103. 
program combines standard programming with Aboriginal spirituality, and is offered at several penal institutions across Canada. An evaluation found that that over two-thirds of those who completed the program were not returned to federal penitentiary over a one-year follow up period. Of those offenders who were returned for a violent offence, those who completed the program were at a rate as low as 7 percent in contrast to 57 percent for a comparison group that had not completed the program. ${ }^{197}$

An evaluative study of the Regional Treatment Centre Sex Offender Treatment Programme in Ontario, that involved a comparison of 64 treated sexual offenders and 55 untreated offenders, found that those who completed the program had recidivism rates approaching zero. This included offenders who scored low, and offenders who scored high, on the PCL-R list. It must be noted that the program was designed for those deemed to be high risks to sexually re-offend. ${ }^{198}$

A study by Ellerby and MacPherson also found that culturally appropriate programming was far better at managing risk. Aboriginal offenders had higher completion rates (83.3 to 55.2 percent), were more likely to continue treatment post-release (59 to 39 percent), for culturally appropriate programming than for standard programming. ${ }^{199}$ Recidivism rates for both Aboriginal and Non-Aboriginal offenders were significantly reduced for those offenders who successfully completed their programs. ${ }^{200}$

The Tupiq program, operated in Ontario, is an intensive therapy program for Inuit sexual offenders that includes Inuit cultural elements. An early evaluation of the program was positive. The program had a 93 percent completion rate, where previously many Inuit offenders did not complete standard programming. The evaluation concluded, based on interviews with program staff and participants, that participants experienced improvements in behaviour, greater acceptance of responsibility, as well as reduced criminogenic needs. Of eleven offenders who were released, only two offenders were returned for technical parole violations, and one for re-offending. ${ }^{201}$

Douglas Heckbert and Douglas Turkington did a study based on interviews with 68 Aboriginal persons who avoided conflict with the law for two years following release from prison. Almost all of the respondents cited familial disruption as a key factor in their criminal histories. Seventy-two percent indicated that meetings with Elders was a key factor in staying out of trouble, and 71 percent indicated that participating in cultural and spiritual ceremonies was a key factor. It must be noted, however, that the respondents often indicated a multitude of factors involved with successful release, such as family suppport, education opportunities,

Shelley Trevethan, John-Patrick Moore \& Nicole Allegri, The "In Search Of Your Warrior Program" for Aboriginal Offenders: A Preliminary Evaluation (Ottawa: Correctional Service of Canada, 2005), online: Government of Canada Publications <http://publications.gc.ca/site/eng/381152/publication. html> at 26.

Jeffrey Abracen et al, "Recidivism among Treated Sexual Offenders and Comparison Subjects: Recent Outcome Date from the Regional Treatment Centre (Ontario) High-Intensity Sex Offender Treatment Programme” (2011) 17:2 Journal of Sexual Aggression 142.

199 Ellerby \& MacPherson, supra note 61 at 49-51.

Ibid at 52.

Shelley Trevethan, John-Patrick Moore \& Leesie Naqitarvik, The Tupiq Program for Inuit Sexual Offenders: A Preliminary Investigation (Ottawa: Correctional Service of Canada, 2004), online: Government of Canada Publications <http://publications.gc.ca/site/eng/380691/publication.html>. 
and steady employment. ${ }^{202}$ A survey of Aboriginal psychiatric patients in the Regional Psychiatric Centre in Saskatchewan found that greater participation in Aboriginal spiritual activities correlated positively with overall satisfaction with life, and correlated inversely with depression. ${ }^{203}$

A psychology thesis by Theresa Howell also explored factors that contribute or detract from successful reintegration of Aboriginal inmates post-release. This study was based on interviews with 42 Aboriginal inmates using the critical incident technique whereby the inmates identified factors that facilitated or obstructed successful release. Inmates identified identity transformation (69 percent), cultural and traditional experiences (60 percent), healthy relationships (79 percent), freedom from prison (60 percent), purpose and fulfillment in life (48 percent), staying drug and alcohol free (38 percent), and professional support and programming (29 percent) as crucial to successful reintegration. They identified unhealthy relationships (41 percent), substance abuse (41 percent), and lack of opportunity and professional support (36 percent) as obstacles to successful release. ${ }^{204}$

A significant body of evidence suggests that extensive programming that includes Aboriginal culture and spirituality that addresses the criminogenic needs of Aboriginal accused can better manage the risk of recidivism, not just at the preventative stage before criminal proceedings are commenced but also after release from incarceration. This in turn suggests that risk assessment of Aboriginal accused should stress dynamic factors as reflected in completion of such programs and ongoing progress with behaviour. In 1996, James Bonta and Laurence Motiuk suggested that there needs to be a refinement in risk assessment for Aboriginal Dangerous Offenders, including the PCL-R checklist. ${ }^{205}$ James Bonta and others have also gone a little further and suggested that there needs to be a risk assessment tool developed for dangerous sexual offenders. ${ }^{206}$ The available evidence may suggest that Aboriginal-specific risk assessment tools with a dynamic emphasis need to be developed so that Canadian courts have a better basis on which to decide whether an Aboriginal accused should be designated as a DO or as an LTO.

Some research is beginning to emerge on this question as well. An Australian study by Alfred Allan and Deborah Dawson explored the possibility of a risk-prediction scale specific to Aboriginal violent and sexual offenders. Although the study ultimately did not purport to construct such an instrument, it had a good deal to say about the application of risk assessment to Aboriginal offenders. The study was critical of prevailing instruments as placing inordinate emphasis on static factors reflected in past criminal history, and not placing enough emphasis on dynamic factors associated with offenders' crimogenic needs. The study also found that the three best predictors of re-offending for male Aboriginal sexual

Douglas Heckbert \& Douglas Turkington, “Turning Points: Factors Relating to the Successful Reintegration of Aboriginal Offenders” (2002) 14:3 Forum on Corrections Research 55.

Mansfield Mela et al, "The effect of religiosity and spirituality on psychological well-being among forensic patients in Canada” (2008) 11:5 Mental Health, Religion \& Culture 517.

Teresa Howell, The Point of No Return: Aboriginal Offenders' Journey Towards a Crime Free Life (D Phil Thesis, Psychology: University of British Columbia, 2008) [unpublished].

James Bonta \& Laurence L Motiuk, High Risk Violent Offenders in Canada (Ottawa, Ontario: Correctional Service of Canada, 1996), online: Government of Canada Publications <http://publications. gc.ca/site/eng/379495/publication.html>.

James Bonta et al, “The Dangerous Offender Provisions: Are they Targeting the Right Offenders?” (1998) 40:4 Can J Crim 377. 
offenders were unrealistic long-term goals, unfeasible release plans, and poor coping skills, a model since named the 3-Predictor. Emphasizing these three risk factors had a predictive accuracy rate for recidivism at 92.3 percent, and a predictive accuracy rate for desistance at 94.3 percent. The study does caution that the sample for this study, 159 Aboriginal sexual offenders, was comparatively small. ${ }^{207}$ Allan and Dawson then did a follow up study on 3-Predictor, and found that it predicted sexual recidivism better than Static-99 when tested for a sample of 538 sexual offenders that included both Aboriginal and non-Aboriginal offenders. The study asserts that tools based on static factors, like Static-99, should not be used for Aboriginal persons without further research. ${ }^{208}$

The mental health professions on which the legal system relies for the relevant expertise during DO hearings have yet to grapple in earnest with important yet outstanding questions. Until that happens, it is probably unrealistic to expect judges to fully appreciate the complexities involved with managing the risk presented by Aboriginal accused who are subjected to DO applications. Further research is certainly needed. Perhaps the culmination of such research could be the design of an Aboriginal-specific risk instrument that stresses dynamic factors, such as the availability of programming that addresses the criminogenic needs of Aboriginal accused, and current progress with behaviour. If such an instrument were to gain wider acceptance, then perhaps it could be incorporated into judicial education as well.

There is of course no point in designing Aboriginal-specific instruments unless there are the programs and services to make LTO orders meaningful for Aboriginal accused. That is a whole issue unto itself, as the availability of such programs and services have sometimes been the crucial point on which a judge will decide to designate an Aboriginal accused as an LTO instead of a DO. In R. v. McNabb, Dr. Wormith stated in his report, "I also believe that the standard group-based, correctional treatment programs are unlikely to be terribly effective, if his history of abuse and related trauma are not addressed with some intensity."209 The availability of resources in the accused's community to make long-term supervision and treatment tenable was what persuaded Justice Kitely in R. v. Mumford to grant an LTO order notwithstanding differences between the expert opinions. ${ }^{210}$

Unfortunately, there is also a lack of programs available for DOs in general, let alone programs that can address the specific needs of Aboriginal DOs. Judges have expressed frustration with this reality. In $R$. $v$. Francis, the Crown experts held out that there was little possibility of eventual control, and relied on the accused's criminal past as the best indicator of future risk. Justice Trussler of the Alberta Court of Queen's Bench agreed with this assessment in designating the accused as a DO, but also offered this insight:

My impression from listening to all of the evidence in this case, particularly that of prison employees and professionals that work in the prison system is that prison treatment programs leave a lot to be desired. They

Alfred Allan \& Deborah Dawson, Developing a Unique Risk of Violence Tool for Australian Indigenous Offenders (Churchlands, West Australia: Criminology Research Council, 2002) at 19, 39-40, 42.

Alfred Allan, Deborah Dawson \& Maria Allan, "Prediction of the Risk of Male Sexual Reoffending in Australia” (2006) 41:1 Australian Psychologist 60.

$R v M c N a b b, 2008$ SKQB 479 at para 65, 80 WCB (2d) 826.

$R v$ Mumford, 200775 WCB (2d) 784, 2007 CLB 2201 at paras 260, 265-82 [Mumford]. See also $R v$ Jack, 2009 ABQB 232, 83 WCB (2d) 215; $R v$ Haines, 2009 BCSC 1505, 85 WCB (2d) 111. 
tend to be group programs and are what I would call "cookie cutter" programs. There is little in the way of specialized, individualized treatment programs. ${ }^{211}$

Justice Kitely noted in Mumford:

\begin{abstract}
Correctional Service Canada does not have unlimited resources. However, according to Dr. Gojer, in order to manage those resources, the priority is given to offenders with determinate sentences. Virtually no resources are allocated to those with indeterminate sentences. As Dr. Gojer said, if the court makes a declaration that an offender is dangerous, it amounts to locking up the offender and throwing away the key. He noted that only $1 \%$ of those declared to be dangerous offenders ever get out. On the other hand, a determinate sentence followed by a long term offender order will put pressure on CSC to develop and implement a plan. It was his view that LTO orders sensitize parole and medical authorities to respond to the needs of the offender. This evidence was not challenged in cross-examination.
\end{abstract}

That means that an indeterminate sentence is in reality a life sentence because, unless the offender achieves some miraculous self-realized transformation, the Parole Board will never grant parole. ${ }^{212}$

Furthermore, a practical incentive exists for governments to invest in these kinds of services, as there is to invest in preventative initiatives. If Aboriginal accused do not have the support necessary to make LTO orders feasible, more of them will be condemned to DO designations. In turn, if Aboriginal DOs do not have any access to programs and services that can meet their specific criminogenic needs, then their DO orders will amount to life sentences. The tally to keep the significant number of Aboriginal DOs detained for the rest of their lives, often from their thirties onwards, promises to be enormous. One could say that pushing an alternative policy is just as much about the fair and humane treatment of Aboriginal accused facing DO designations, but there is a practical incentive for this as well.

\title{
VII. CONCLUSION
}

There is, just as with Aboriginal over-incarceration generally, a serious problem with Aboriginal over-representation as DOs. There is a definite degree to which the problem transcends the legal system itself, and speaks to far deeper problems in society at large. So long as the social legacies of colonialism endure and Aboriginal communities are left deeply damaged and unhealed, many Aboriginal persons will continue to themselves endure multiple and severe traumas. This will set them up for lives of crime, and many among those will go on to be marked as DOs to be detained indefinitely. Canada, however, continues to prioritize more and more an enormously expensive policy of incarceration. Investments into social programming that could address the underlying causes behind Aboriginal crime are minimal by comparison. The concept of "Justice Reinvestment" is thus far relatively unexplored, but it is one that American states are now beginning to experiment after having taken their turns with expensive tough on crime policies. Canada needs to begin serious consideration for this kind of policy as well. Justice reinvestment may require more resources in the short term, but failing to address the social conditions behind Aboriginal crime in any meaningful fashion will surely demand a far greater tally over the long haul. If Canada 
continues on its present course, the problems of both Aboriginal over-incarceration generally and Aboriginal over-representation as DOs will continue unabated. In fact, what may be required is not just a generic justice reinvestment policy, but a justice reinvestment policy whereby Canada works in a genuine partnership with Aboriginal communities to tackle the problem in earnest. The programs and services need to draw upon the healing resources of Aboriginal cultures so as to best reach the people in need of them. There is empirical support, albeit limited, that verifies that such an approach is tenable, even necessary.

Even so, attention must be given to those who are already, or soon will be, subject to DO applications. There is legal authority that mandates that DO determinations take into consideration the Gladue factors, but questions surround the extent to which this is realized in practice. DO determinations hinge almost exclusively on risk instruments that rely on static factors tied with past criminal conduct. These instruments, while on the surface neutral and objective, may not provide sufficient consideration to dynamic factors that are relevant to the criminogenic needs of Aboriginal accused. And again, there is limited empirical evidence to suggest that dynamic factors such as current progress with behaviour and responses to culturally-based programming may be better predictors of risk, at least for Aboriginal accused, than the standard instruments. This in turn begs the question of whether an Aboriginal-specific risk instrument should be developed for when Aboriginal accused face DO applications. However, for any of this to be feasible, the resources must be made available for LTO release plans to be workable. Resources must also be made available to those Aboriginal accused who are designated as DOs so that there can be a meaningful opportunity for them to rehabilitate and obtain parole. And again, the justice reinvestment theme becomes relevant. It may be more cost-effective in the long run (and more humane besides) to make initial investments in programs and services for LTO plans, and provide programs and services to those Aboriginal accused who are designated as DOs, than to keep many Aboriginal persons detained for the rest of their lives. 